\title{
Laser Soldering Properties of MEMS Probe for Semiconductor Water Testing
}

\author{
반도체 검사 프로브 카드용 MEMS 프로브의 레이저 솔더링 접합특성 \\ Won Sik Hong*, ${ }^{*}$ Mi-Song Kim*, Myeongin Kim*, Sang-Hyuk Yun**, and Yunhwi Park** \\ *Electronic Convergence Materials \& Device Research Center, Korea Electronics Technology Institute, \\ Seongnam, 13509, Korea \\ **Research Institute, Korea Instrument Co. Ltd., Gyeonggi-do, 18487, Korea \\ †Corresponding author: wshong@keti.re.kr \\ (Received August 7, 2021; Revised August 11, 2021; Accepted August 17, 2021)
}

\begin{abstract}
In this study, the laser soldering process of microelectromechanical system (MEMS) probes and multilayer ceramic (MLC) substrates was optimized with Type 4 (T4) and Type 7 (T7) Sn-3.0Ag-0.5Cu (SAC305), Type 4 Sn-0.3Ag0.7 Cu (SAC0307), and Type $4 \mathrm{Sn}-5.0 \mathrm{Sb}$ ( $\mathrm{SnSb}$ ) soldering, and the probe solder joint properties were compared. $\mathrm{SAC} 0307$ and $\mathrm{SnSb}$ were used to confirm the bonding property of the low-Ag solder and the high-temperature durability. We conducted a thermal cycling test (TCT) with 500 cycles at temperatures of $-25{ }^{\circ} \mathrm{C}$ to $105{ }^{\circ} \mathrm{C}$ with a 10-min dwell time at each temperature. Before and after the TCT, the microstructure of solder joint as well as the shear strength between the probe and the MLC were examined. The results revealed that, after the TCT, the degradation rate of T7 SAC305 solder was lower than that of T4 SAC305, and the SnSb solder did not exhibit bonding strength degradation. The fracture mode of the SAC solder joint was ductile-brittle. In the case of the SnSb joint, brittle fracture was the major fracture mode because of the $\mathrm{Sn}-\mathrm{Sb}$ intermetallic compounds. The $\mathrm{SnSb}$ solder had an excellent bonding strength and degradation property after the TCT, but the lack of toughness caused brittle fracture. These results confirm the applicability of T4 SnSb and T7 SAC305 solders for high-temperature response and fine pitch bonding.
\end{abstract}

Key Words: Probe card, MEMs probe, Laser, Soldering, Solder, Type 7

\section{Introduction}

A probe card is used as a signal transmission interface used in the wafer inspection process for electrical go/nogo testing of individual chips in the fabricated wafers during the semiconductor manufacturing process. The probe card is a product that is individually designed and fabricated depending on the specifications of the semiconductor device under test (DUT). Since the probe card needs to be newly fabricated for each time the specifications of the device changes, it is categorized as a high value-added product. Also, the probe card is one of the core components for testing fabricated wafers during the semiconductor manufacturing process ${ }^{1}$. In terms of the shape of a probe card, a contact pin or probe with the shape of a very fine line is attached to a Printed Circuit Board (PCB) of a set specification for electrical go/no-go testing of chips in the wafer, and the probe is electrically connected to the wafer, serving as the interface between the wafer and the test system electronics. In this way, $100 \%$ inspection is performed for screening defective semiconductor chips.

In recent trends of probe card technology, memory capacity density continues to increase with the miniaturization of semiconductor process nodes, along with the shrinking of chip size with the same capacity and increase in the number of net die-per-wafer ${ }^{1,2}$. Accordingly, the pad pitch of the IC that the probe card needs to measure decreases, and the number of pins rapidly increases ${ }^{1-5)}$. 
Also, for automotive electronics, with increasing proportion of semiconductor devices (ICs) requiring testing under high-temperature environment, the temperature in the wafer testing during the semiconductor manufacturing process has increased to more than $120{ }^{\circ} \mathrm{C}$. Consequently, there is a pressing need for high temperature durability in the joint between the probe and solder of the substrate.

As shown in Fig. 1 below, the general structure of a probe card consists of a MEMS (microelectromechanical systems) probe that applies electrical signals to the panel and semiconductor device patterns, multilayer ceramic (MLC), PCB, interposer, connector, jig and fixture. The probe card should have low contact resistance, as well as durability, service life for more than 100,000 times of cyclic fatigue tests (Fatigue test or Touch down (T/D)), and small thermal deformation under $-40^{\circ} \mathrm{C}-100^{\circ} \mathrm{C}^{1)}$.

The MEMS probe card is joined on the MLC pad by laser (Light Amplification by the Stimulated Emission of Radiation) soldering using $\mathrm{Pb}$-free solders. For methods of MEMS soldering, the conventional reflow method can be used, but in this case, thermal stress is applied to the MLC substrate, leading to high possibility of short circuit and substrate fracture. Therefore, se-

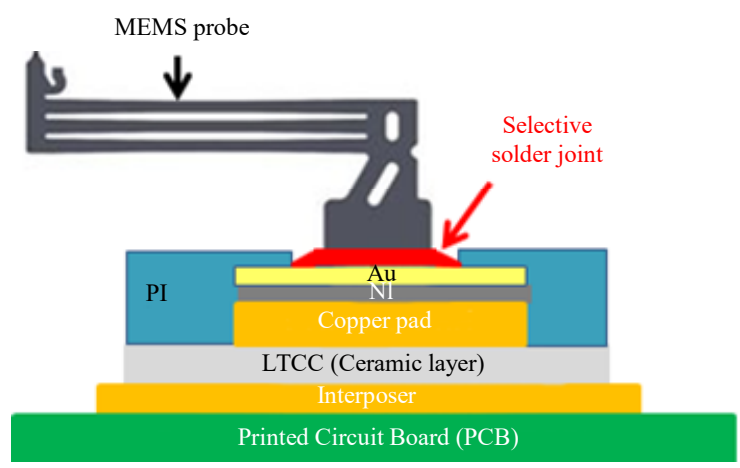

Fig. 1 Schematic diagram of MEMS probe solder joint lective soldering method is used in which the MEMS probe is bonded to the individual pad of MLC substrate using laser. In the laser soldering process, soldering is performed by individually applying heat through laser optics for each pad with a size of several tens to hundreds of $\mu \mathrm{m}$. The advantage of this method is that thermal and mechanical stresses are not applied to the MLC substrate during the soldering process. In terms of solders used for probe soldering, there has been a recent trend of shift from $\mathrm{Pb}-\mathrm{Sn}$ solder to eco-friendly $\mathrm{Pb}$-free solder. The mainly used $\mathrm{Pb}$-free solders include Sn-3.0Ag-0.5Cu (SAC305), and for improvement in the high temperature durability, application of solders such as $\mathrm{Sn}-0.7 \mathrm{Cu}$ or $\mathrm{Sn}-5 \mathrm{Sb}$ with high melting points is being investigated.

Therefore, in this study, a laser soldering process for probe-MLC soldering was developed taking into account the high temperature durability and responses to fine pitch requirements. In the developed laser soldering process, SAC305 Type 4 (T4) (Powder size: 20-38 $\mu \mathrm{m}$ ) and Type 7 (T7) (Powder size: 2-11 $\mu \mathrm{m})$ solder pastes were used. In addition, Sn-0.3Ag-0.7Cu (SAC0307) T4 solder was used for comparison of bonding properties of solders with low-Ag, and for implementation of high-temperature durability, $\mathrm{Sn}-5.0 \mathrm{Sb}$ ( $\mathrm{SnSb}) \mathrm{T} 4$ solder was used to perform the probe soldering process. Next, thermal shock tests were performed to compare the high temperature durability of the soldered joints, the shear strength of the probe solder joint was measured before and after the test, and the soldering properties were comparatively analyzed through the cross-sectional analysis of the microstructure of the as-soldered joints.

\section{Methods}

\subsection{Probe, MLC and Pb-free solder paste}

Fig. 2 presents the images of the probe and MLC sub-
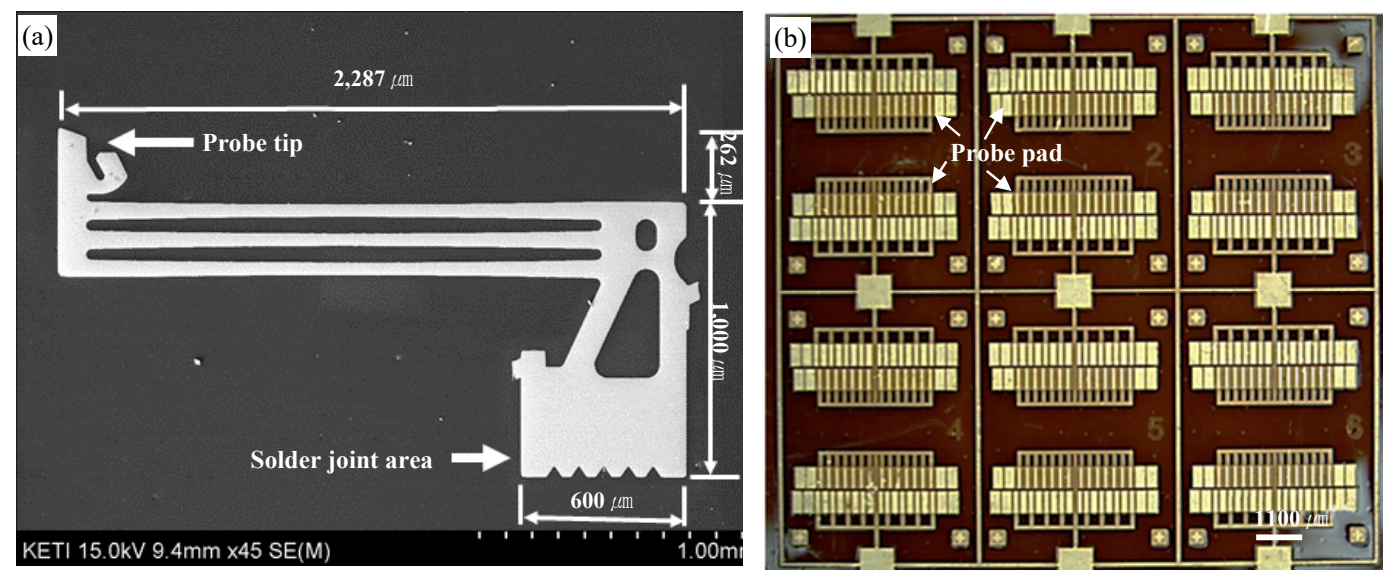

Fig. 2 SEM micrograph of (a) MEMS probe and optical stereo-microscope image of (b) MLC 
Table 1 Chemical composition, type, and powder size of $\mathrm{Pb}$-free solder pastes

\begin{tabular}{|c|c|c|c|}
\hline Solder alloy composition & Solder paste type & Powder size $(\mu \mathrm{m})$ & Manufacturer \\
\hline \multirow{2}{*}{ Sn-3.0Ag-0.5Cu (SAC305) } & $\mathrm{T} 4$ & $20-38$ & Ecojoin Co., Ltd.(Korea) \\
\cline { 2 - 4 } & $\mathrm{T} 7$ & $2-11$ & Duksan Hi-Metal Co., Ltd.(Korea) \\
\hline $\mathrm{Sn}-0.3 \mathrm{Ag}-0.7 \mathrm{Cu}(\mathrm{SAC} 0307)$ & $\mathrm{T} 4$ & $20-38$ & Ecojoin Co., Ltd.(Korea) \\
\hline $\mathrm{Sn}-5.0 \mathrm{Sb}(\mathrm{SnSb})$ & & & \\
\hline
\end{tabular}

strate used in the experiment. For the MEMS probe, nickel alloys plated with gold $(\mathrm{Au})$ at a thickness of 25-34 $\mu \mathrm{m}$ was used. The dimension of the MLC substrate was $25(\mathrm{~L}) \times 25(\mathrm{~W}) \mathrm{mm}$, that of the pad for bonding to the probe was $750(\mathrm{~L}) \times 120(\mathrm{~W}) \mu \mathrm{m}$, and the pad pitch size was $250 \mu \mathrm{m}$. The thickness of the $\mathrm{Cu}$ pad was approximately $23 \mu \mathrm{m}$, and the surface of $\mathrm{Cu}$ pad was treated with $\mathrm{Ni} / \mathrm{Au}$ electro-plating.

As for types of solders used in the probe soldering process, a total of 4 types of solder paste were used as outlined in Table 1 below. They include T4 SAC305 solder, which is the typical solder currently used, T7 SAC305 for fine pitch requirement, and T4 SAC0307 solder for comparison of improvement in the thermal fatigue. For investigation of high temperature durability, SnSb solder was used for the soldering process.

\subsection{Laser Soldering Process and Laser Soldering Profile}

A soldering process using a laser was performed for the probe-MLC bonding process. Fig. 3 is a photograph depicting the laser soldering process. The fiber laser source used in the experiment is Pearl ${ }^{\mathrm{TM}}$ of nLight with a wavelength of $808 \mathrm{~nm}$, a wave tolerance range of $\pm 3 \mu \mathrm{m}$, and a power output of $55 \mathrm{~W}$.

The laser soldering profile used in the laser soldering process is shown in Fig. 4. Fig. 4(a) shows the laser profile for SAC305 solder, and Fig. 4(b) shows the laser profile for $\mathrm{SnSb}$ solder. The soldering process was performed by irradiating the laser for a total of $2.5 \mathrm{~s}$ for $\mathrm{SAC} 305$ solder and $3 \mathrm{~s}$ for $\mathrm{SnSb}$ solder. In the case of $\mathrm{SnSb}$ solder with a melting point of $232-240{ }^{\circ} \mathrm{C}$, higher compared to SAC305 solder with a melting point of
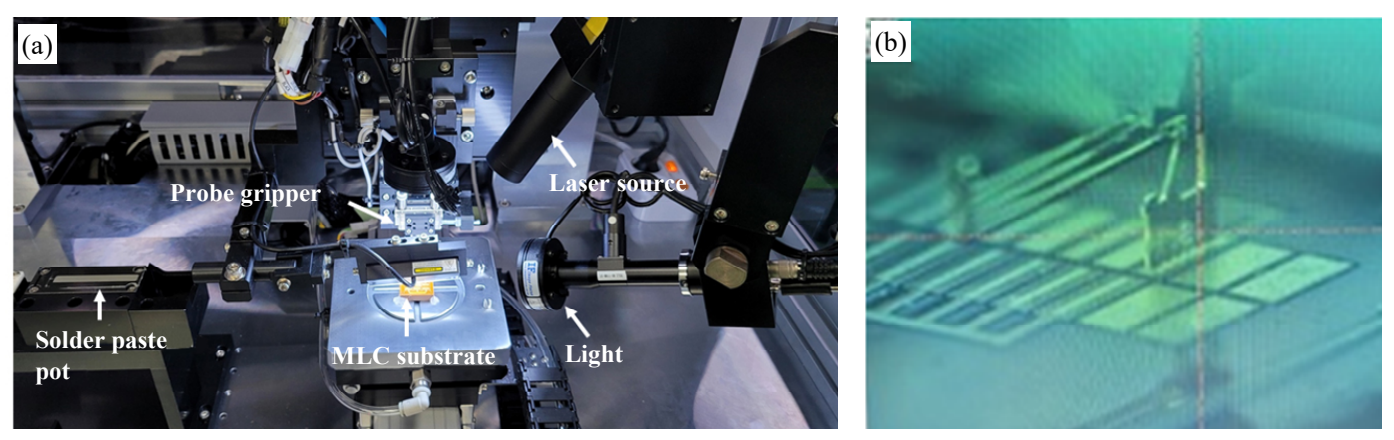

Fig. 3 Photographs of (a) laser soldering process with (b) MEMS probe and MLC

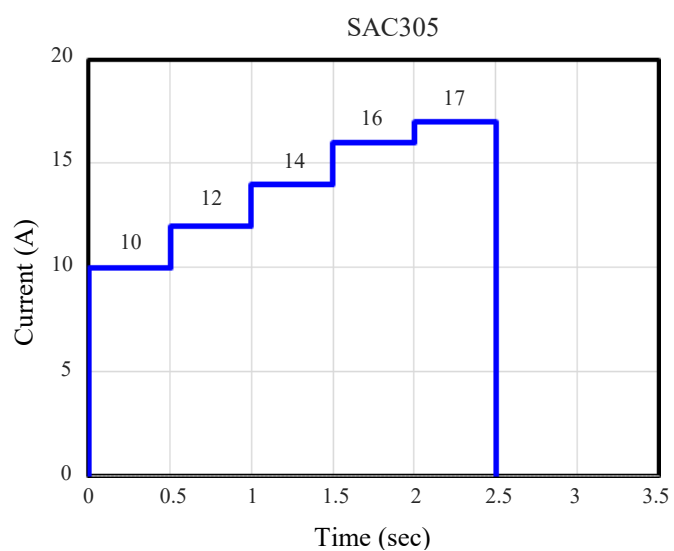

(a)

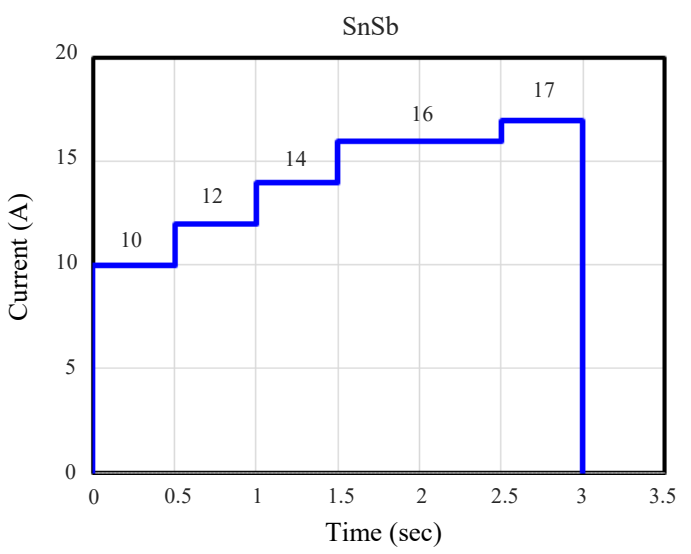

(b)

Fig. 4 Laser soldering profiles for (a) SAC305 and (b) SnSb solders 
$217{ }^{\circ} \mathrm{C}$, the laser was additionally irradiated by $0.5 \mathrm{~s}$ at 16 A. Due to the high melting point of the solder, additional irradiation of a high-power laser was required to induce complete melting of the solder.

\subsection{Thermal Cycling Test (TCT)}

For analysis of the bonding strength degradation property of the probe joint, 500 cycles of TCT was performed under the conditions of $-25-105{ }^{\circ} \mathrm{C}$ and $10 \mathrm{~min}$ holding time for each temperature condition $^{5,6)}$. Then, the shear strength of the probe joint was measured. In general, the shear strength standard after TCT is within about $40 \%$ of the shear strength of the as-soldered joints.

\subsection{Measurement of Solder Joint Strength}

For measurement of the bonding strength of the ProbeMLC solder joint, a shear strength test was performed as shown in Fig. 5 using Dage 4000 (Nordson Co. Ltd., USA) bondtester. The shear strength test was performed under the conditions of a test speed of $50 \mu \mathrm{m} / \mathrm{sec}$ and the height of the test fixture at $500 \mu \mathrm{m}$ from the substrate, and the bonding strength was comparatively analyzed with respect to different solder alloy composition and solder paste types.

\section{Results}

\subsection{Bonding Strength Analysis of Probe Solder Joint}

For the analysis of the degradation property in the bonding strength of the probe joint, after 500 thermal cycles, the shear strength of the probe solder joint was measured and the level of degradation was comparatively analyzed against the shear strength of the as-soldered joint. The result was presented in Fig. 6, and in all samples, degradation within $0 \%-17 \%$ was ob-

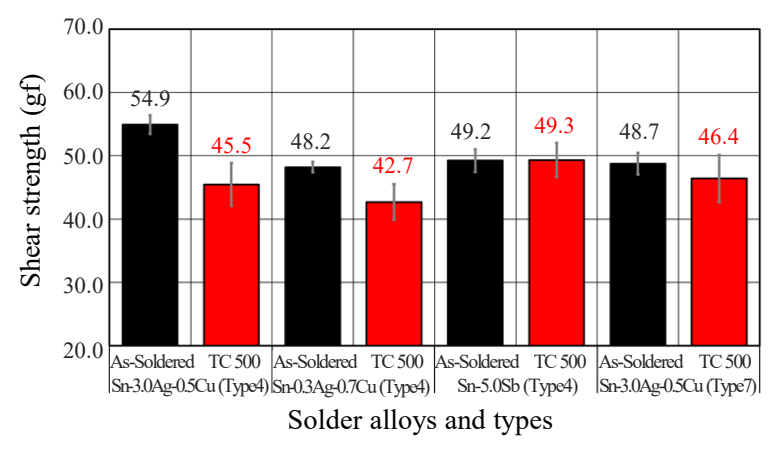

Fig. 6 Shear strength comparison of laser solder joints before and after thermal cycles

served compared to the shear strength of the as-soldered joint, indicating good bonding state. The shear strength of T4 and T7 SAC305 solder joint was $54.9 \mathrm{gf}$ and 48.7 gf, respectively, and after TCT, the shear strength was decreased to $45.5 \mathrm{gf}$ and $46.6 \mathrm{gf}$, respectively. Although T4 SAC305 showed slightly higher shear strength of the as-soldered joint than $\mathrm{T} 7$ SAC305, the degradation rates after TCT were $17.1 \%$ and $5.5 \%$, respectively, indicating that $\mathrm{T} 7$ solder showed a lower degradation rate. The shear strength of T4 SAC0307 decreased to 42.7 gf after TCT from 48.2 gf at as-soldered joint, indicating the degradation rate of shear strength at $11.4 \%$. For T4 SAC0307 solder joint, the shear strength of the as-soldered joint was slightly smaller than that of T4 SAC305 but the degradation rate after TCT was smaller than that of T4 SAC305, and the as-soldered joint shear strength was similar level to that of T7 SAC305. In the case of T4 $\mathrm{SnSb}$ solder joint, the as-soldered joint shear strength was lower than that of T4 SAC305, but was similar level to that of T4 SAC0307 and T7 SAC305 joints. Furthermore, considering that there was no bonding strength degradation after 500 thermal cycles in TCT, it can be seen that T4 SnSb solder has excellent high tem-
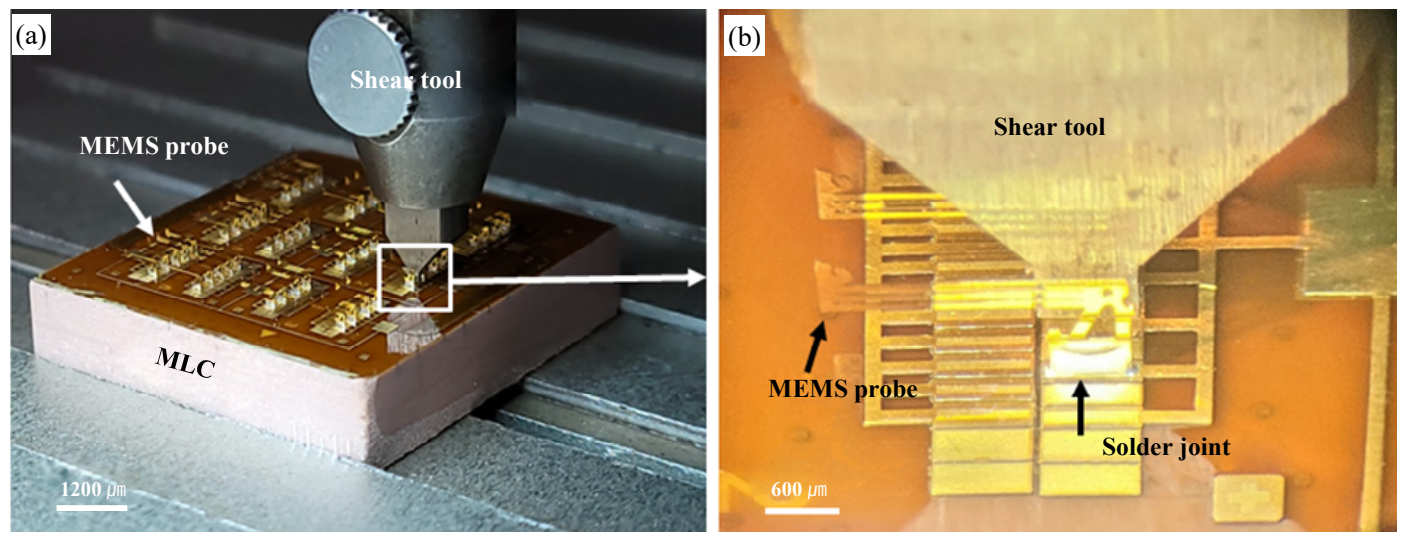

Fig. 5 Photographs of shear strength measurement of probe solder joint, (a) overview of probe-MLC bonded coupon and (b) magnified view of probe solder joint 
perature durability and degradation property.

\subsection{Cross-sectional Analysis of As-soldered Probe- MLC Joint}

The results of cross-sectional analysis of each type of solder joint after performing optimization of the probeMLC bonding process using 4 types of solder are presented in Figs. 7 and 8 below. Fig. 8 is the magnified SEM images of the probe-solder joint and solder-MLC joint interface. In Fig. 7 (a-h) is the cross-sectional SEM images after probe-MLC bonding using T4 SAC305 (a, b), T4 SAC0307 (b,c), T4 SnSb (e,f), and T7 SAC305 solder $(\mathrm{g}, \mathrm{h})$. Fig. $8(\mathrm{a}-\mathrm{h})$ is the SEM images of the probe-MLC joint using 4 types of solders, respectively, and Fig. $8(\mathrm{i}, \mathrm{j})$ represents the magnified SEM image and EDS component analysis result for T7 SAC 305 solder joint interface. It can be seen that fillets were well formed in the probe solder joints, and various types of intermetallic compounds (IMC) were formed on the interface of probe solder joints. Regardless of the type, in the $\mathrm{Pb}$-free solder joint of $\mathrm{SAC} 305$ and $\mathrm{SAC} 0307, \mathrm{Ni}_{3} \mathrm{Sn}_{4}(\mathrm{Cu}, \mathrm{Ni})_{6} \mathrm{Sn}_{5}$ and $(\mathrm{Cu}, \mathrm{Ni}, \mathrm{Au})_{6} \mathrm{Sn}_{5}$
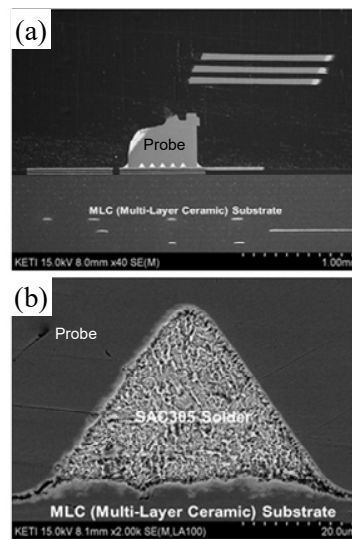
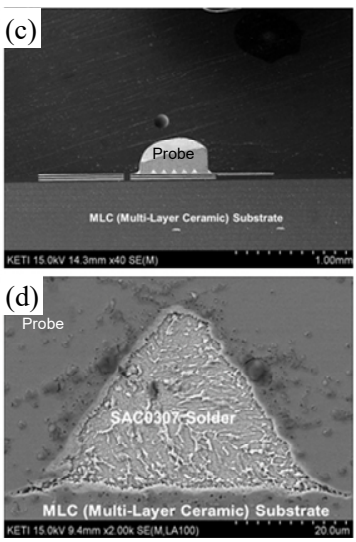
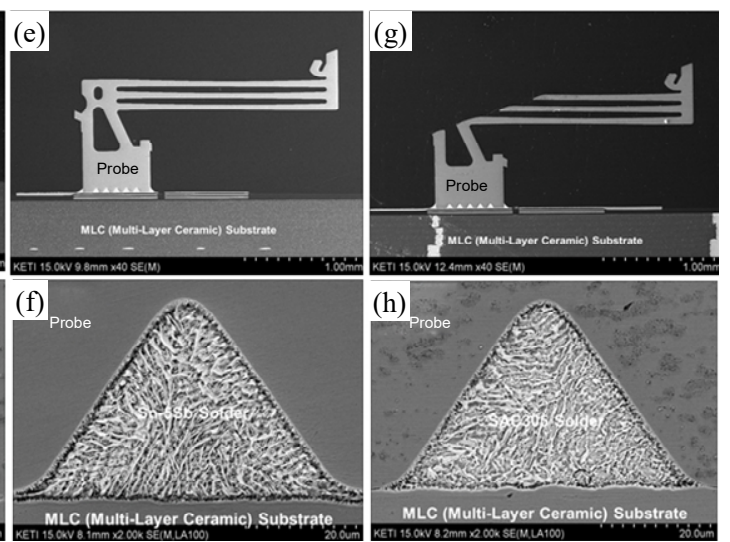

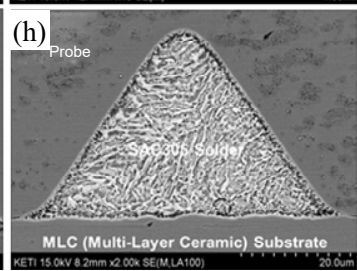

Fig. 7 Cross-sectional SEM micrographs of as-soldered probe-MLC joints, (a,b) T4 SAC305, (b,c) T4 SAC0307, (e,f) T4 $\mathrm{SnSb}$, and (g,h) T7 SAC305
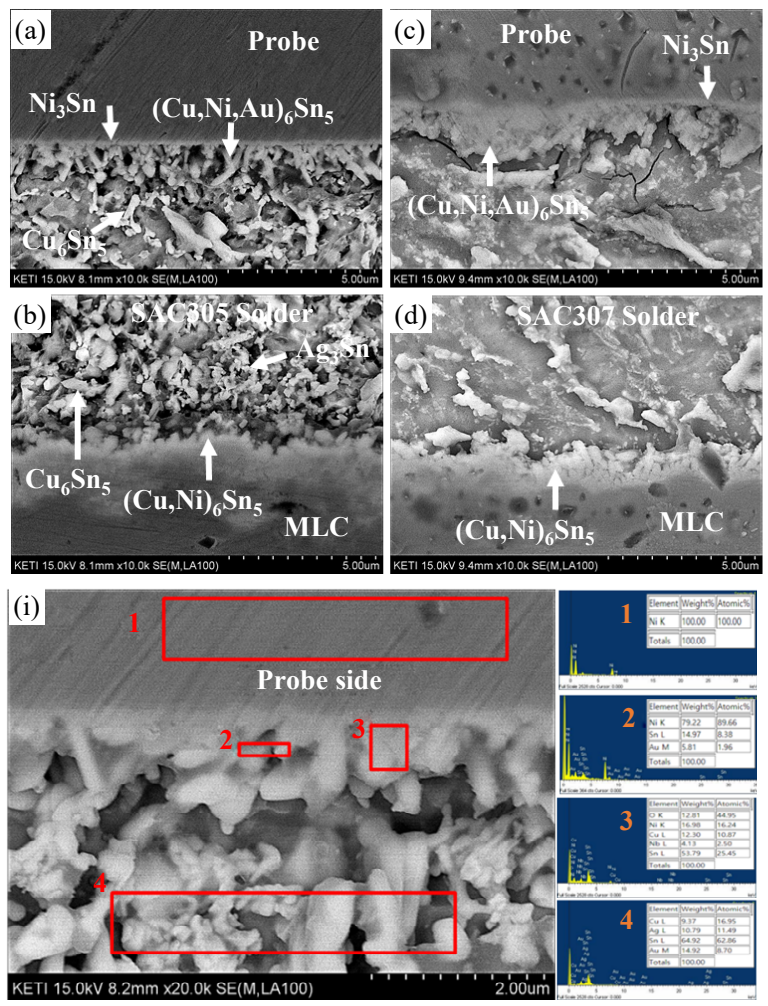
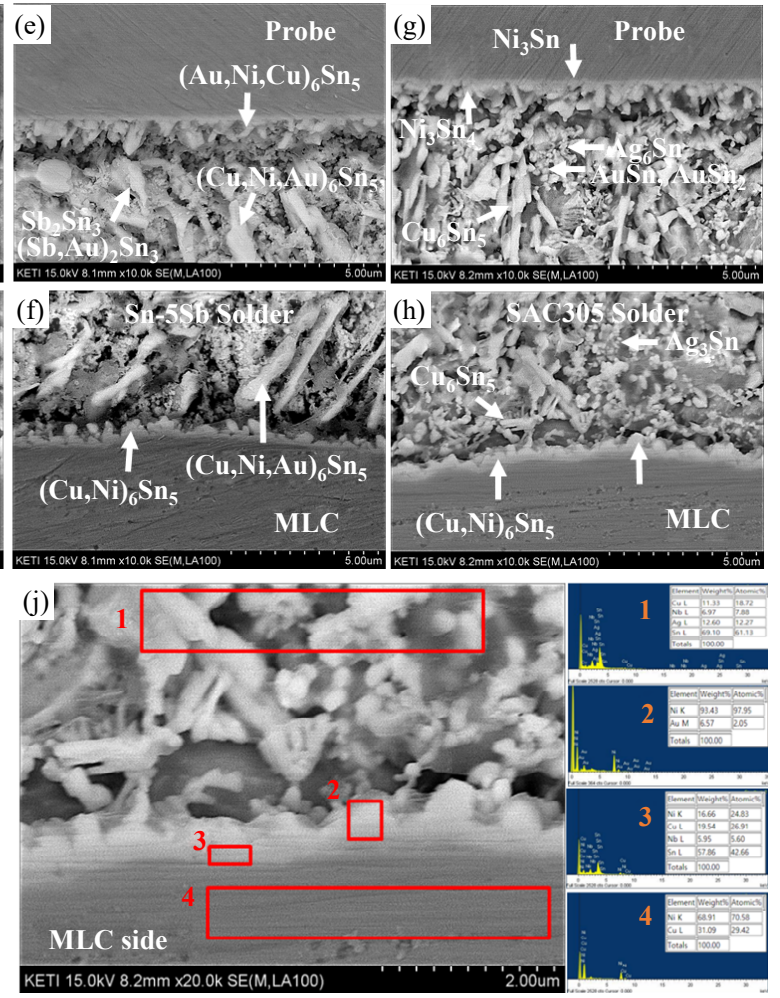

Fig. 8 Magnified SEM images of as-soldered Probe-MLC joints, (a,b) T4 SAC305, (b,c) T4 SAC0307, (e,f) T4 SnSb, $(\mathrm{g}, \mathrm{h}) \mathrm{T} 7 \mathrm{SAC} 305$, and $(\mathrm{i}, \mathrm{j})$ magnified images of the probe and the MLC joint of T7 SAC305 
IMCs were formed on the interface of probe solder joint, and on the solder base metal, $\mathrm{Ag}_{3} \mathrm{Sn}, \mathrm{Au}_{\mathrm{x}} \mathrm{Sn}_{\mathrm{y}}$, $\mathrm{Cu}_{6} \mathrm{Sn}_{5}$, and $(\mathrm{Cu}, \mathrm{Ni}, \mathrm{Au})_{6} \mathrm{Sn}_{5}$ IMCs were formed $\left.{ }^{7-15}\right)$. Since the surface of the probe is plated with $\mathrm{Ni} / \mathrm{Au}$, various types of Au-Sn IMCs were observed inside the solder joint. There are four types of Au-Sn IMCs that can be formed inside the solder joint: $\mathrm{AuSn}, \mathrm{Au}_{2} \mathrm{Sn}$, $\mathrm{AuSn}_{2}$, and $\mathrm{AuSn}_{4}{ }^{8}$. In Fig. 7 (b,d,h), comparing the microstructure formed inside the SAC305 solder, it can be seen that less $\mathrm{Ag}_{3} \mathrm{Sn}$ IMCs are formed with SAC0307 solder than with SAC305 solder. This is because the amount of $\mathrm{Ag}_{3} \mathrm{Sn}$ formed in the solder base metal varies with the difference in the Ag content contained in the solder. According to Hong ${ }^{7)}$ and $\mathrm{Suh}^{8)}$, it was reported that the fraction of primary-Sn is up to $11 \%$ for $\mathrm{Sn}-3.0 \mathrm{Ag}-0.5 \mathrm{Cu}$ and up to $35 \%$ for $\mathrm{Sn}-1.0 \mathrm{Ag}-0.5 \mathrm{Cu}$, depending on the content of $\mathrm{Sn}$ in the $\mathrm{Sn}-\mathrm{Ag}-\mathrm{Cu}$ alloy composition. With the decrease in the Ag content in the $\mathrm{Sn}-\mathrm{Ag}-\mathrm{Cu}$ alloy composition, the amount of primary-Sn formation is increased and the amount of $\mathrm{Sn}$ to form $\mathrm{Ag}_{3} \mathrm{Sn}$ decreases. Thus, the $\mathrm{Ag}_{3} \mathrm{Sn}$ fraction in the SAC0307 solder is smaller than that of SAC305 solder ${ }^{7}$. The formation of $\mathrm{Ag}_{3} \mathrm{Sn}$ IMCs positively contributes to the improvement of the bonding strength of as-soldered joints, but when exposed to high temperature for a long time, $\mathrm{Ag}_{3} \mathrm{Sn}$ IMCs grow and become coarse, causing a decrease in bonding strength ${ }^{7,10)}$. For this reason, the result of bonding strength comparison after TCT shows that the bonding strength degraded more in the case of SAC305 solder than SAC0307 solder, and this is considered to be due to the coarsening of $\mathrm{Ag}_{3} \mathrm{Sn}$ IMCs formed on the base metal. On the interface of $\mathrm{SnSb}$ solder joint, formation of various IMCs including ( $\mathrm{Au}, \mathrm{Ni}, \mathrm{Cu})_{6} \mathrm{Sn}_{5},(\mathrm{Cu}, \mathrm{Ni})_{3} \mathrm{Sn}, \mathrm{Ni}_{3} \mathrm{Sn}_{4}, \mathrm{Sb}_{2} \mathrm{Sn}_{3}$, $(\mathrm{Sb}, \mathrm{Au})_{2} \mathrm{Sn}_{3}$, and $\mathrm{AuSn}_{4}$ were observed ${ }^{13-15)}$. It can be seen that the formation of these IMCs in the as-soldered joints contributes to the improvement of bonding strength of as-soldered joint after soldering, and in SAC composition, Sn-Sb IMCs are considered to show positive contribution to the enhancement of the high temperature durability.

Fig. 9 presents SEM images of the fracture surfaces after measuring the initial shear strength of the as-soldered probe solder joint for 4 types of the solder paste. The solder joint fracture surface of all samples showed a pattern of the mixed presence of typical ductile fracture with multiple dimples and cleavage fracture, which is brittle fracture ${ }^{12)}$. The fracture surface of T4 SAC305 solder joint showed ductile fracture with formation of dimples in the early stage of shear strength test, but from the middle of the test, brittle fracture patterns of cleavage fracture without ribs were shown. For T4 SAC0307 solder, ductile fracture with formation of dimples was observed in all fracture surfaces, which confirms that compared to $\mathrm{SAC} 305$ solder, less $\mathrm{Ag}_{3} \mathrm{Sn}$ IMCs were formed, thus the strength of ad-soldered joint is decreased but ductility has increased. For T4 $\mathrm{SnSb}$ solder, cleavage brittle fracture with almost no dimples was observed as the major fracture mode of the fracture surface, and some of the surfaces showed semi-cleavage fracture. SnSb solder is a solder with improved hightemperature durability due to the formation of $\mathrm{Sn}-\mathrm{Sb}$
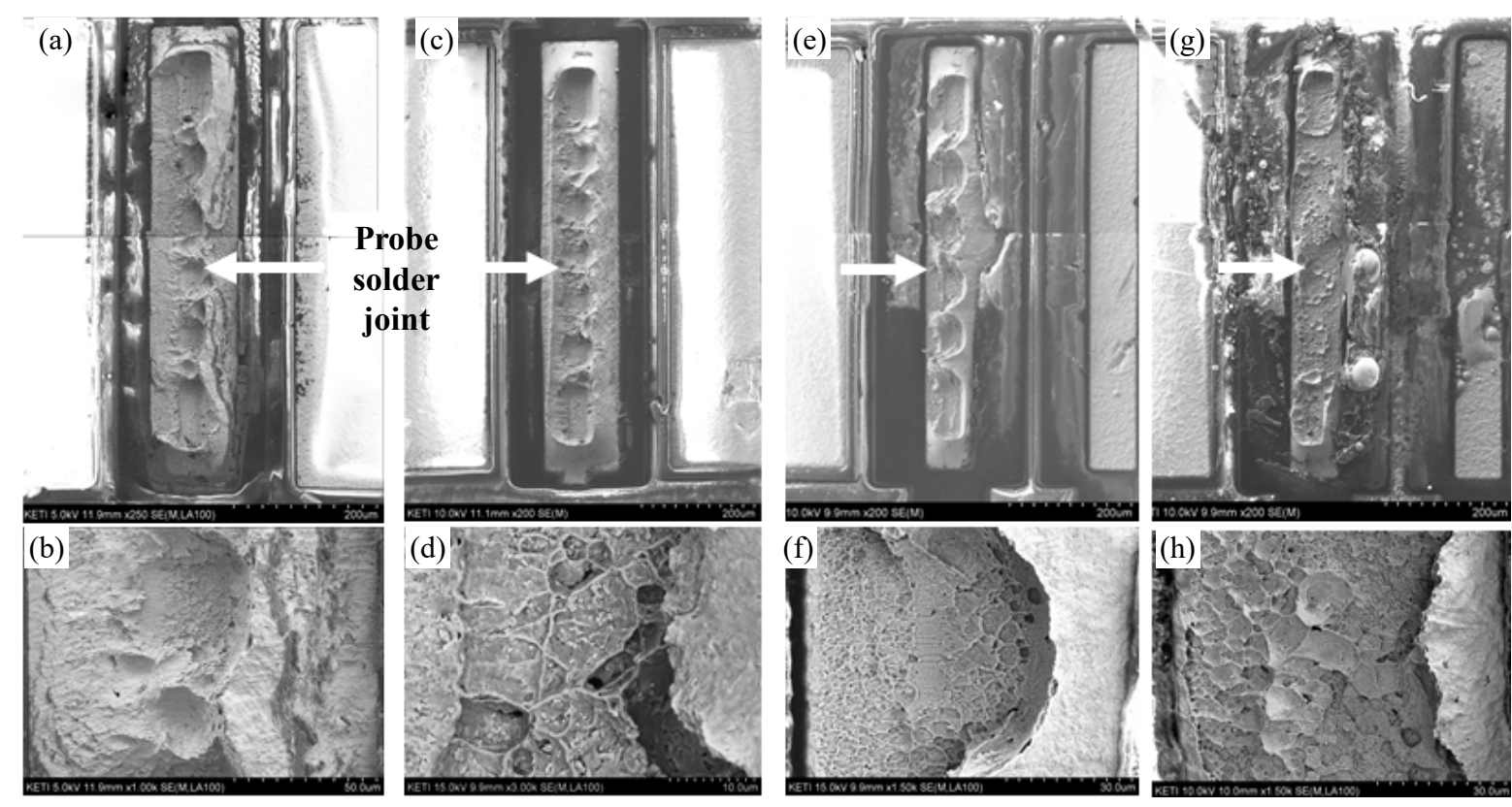

Fig. 9 SEM images of fracture surfaces of as-soldered probe joints after shear strength test, (a,b) T4 SAC305, (b,c) T4 SAC0307, (e,f) T4 SnSb, and (g,h) T7 SAC305 
IMCs, and the image analysis showed that although bonding strength was increased, brittle fracture pattern was shown due to low ductility. In terms of bonding strength, $\mathrm{SnSb}$ solder has excellent bonding strength of the as-soldered joint and a small degradation rate after TCT, but brittle fracture was induced at surface fracture, due to lack of toughness of the solder compared to SAC composition ${ }^{14,15)}$.

\section{Conclusion}

In this study, for improving the high temperature durability of the probe solder joint and meeting the fine pitch requirements in the soldering process, $\mathrm{T} 4$ and $\mathrm{T} 7$ SAC305, T4 SAC0307, T4 SnSb solders were used to perform optimization of probe-MLC laser soldering process. With the developed laser soldering process, the bonding strength degradation rate was comparatively analyzed before and after the thermal cycling test (TCT), and the bonding property was analyzed with respect to changes in the solder alloy composition and powder size. The main findings of this study are outlined as follows

1) T4 SAC305 showed slightly higher shear strength of as-soldered joint compared to that of T7 SAC305, but after TCT, the degradation rate of T7 SAC305 solder was lower than that of T4 SAC305. For SAC305 solder, the shear strength of the as-soldered joint was lower with T7 SAC305 than that of T4 SAC305, but the degradation rate of T7 SAC305 after TCT was lower than that of T4 SAC305. The shear strength of the as-soldered joint of T7 SAC305 was similar to that of T4 SAC0307. For T4 SnSb solder, the as-soldered shear strength was lower than that of T4 SAC305, but it was equivalent to that of T4 SAC0307 and T7 SAC305. Since no bonding strength degradation was observed after 500 thermal cycles of TCT, the excellent high temperature durability and degradation characteristics were confirmed with $\mathrm{SnSb}$ solders.

2) In SAC305 and SAC0307 solder joints, $(\mathrm{Cu}, \mathrm{Ni}, \mathrm{Au})_{6} \mathrm{Sn}_{5}$ IMCs were formed on the interface of the probe-MLC solder joint, and formation of $\mathrm{Ag}_{3} \mathrm{Sn}, \mathrm{Au}_{3} \mathrm{Sn}, \mathrm{Cu}_{6} \mathrm{Sn}_{5}$, and $(\mathrm{Cu}, \mathrm{Ni}, \mathrm{Au})_{6} \mathrm{Sn}_{5}$ IMCs was observed inside the solder. When bonding strength was compared after TCT, higher rate of bonding strength degradation was observed with SAC305 compared to SAC0307. The reason for the difference is that since the amount of $\mathrm{Ag}_{3} \mathrm{Sn}$ formed in the base metal was larger with SAC305 solder than the amount with SAC0307 solder, the bonding strength decreased more with SAC305 after TCT due to the coarsening of $\mathrm{Ag}_{3} \mathrm{Sn}$. On the interface of $\mathrm{SnSb}$ solder joint, various types of IMCs such as $(\mathrm{Au}, \mathrm{Ni}, \mathrm{Cu})_{6} \mathrm{Sn}_{5}$,
$(\mathrm{Cu}, \mathrm{Ni})_{3} \mathrm{Sn}, \mathrm{Ni}_{3} \mathrm{Sn}_{4}, \mathrm{Sb}_{2} \mathrm{Sn}_{3},(\mathrm{Sb}, \mathrm{Au})_{2} \mathrm{Sn}_{3}$, and $\mathrm{AuSn}_{4}$ were observed and it is considered that $\mathrm{Sn}-\mathrm{Sb}$ IMCs have contributed to the improvement in the high temperature durability of the solder.

3) In the fracture surface analysis of the SAC solder joints, mixed presence of ductile fracture and brittle fracture was observed. In the case of fracture surface of T4 SAC0307, ductile fracture was more dominantly observed compared to SAC305, and this is judged to be caused by increased ductility from less formation of $\mathrm{Ag}_{3} \mathrm{Sn}$ IMCs inside the solder. In the case of $\mathrm{T} 4 \mathrm{SnSb}$ joint, cleavage fracture, which is brittle fracture, was shown as the major fracture mode, and brittle fracture was observed due to low ductility although the hightemperature durability was improved due to the formation of Sn-Sb IMCs. SnSb solder is considered to show excellent properties in terms of bonding strength and degradation rate, but the result indicated that brittle fracture was caused due to lack of toughness of the solder.

\section{Acknowledgments}

This work was supported by the Technology Innovation Program - Root(Ppuri) Technology Development Program for Quality Response of Global Core Industry (Grant No.: 20011705) by the Korean Ministry of Trade, Industry and Energy (MOTIE) in the Republic of Korea.

ORCID: Won Sik Hong: http://orcid.org/0000-0001-8398-177X ORCID: Mi-Song Kim: https://orcid.org/0000-0002-4717-9365 ORCID: Myeongin Kim: https://orcid.org/0000-0002-5151-1404

\section{References}

1. Korea Institute of Science and Technology Information (KISTI), Technical Tren of Semi-conductor Measurement and Inspection Equipment, The Ministry of Trade, Industry and Energy (MOTIE) and Materials \& Component Technology Network (MCT-Net), Accessed on https://www.mctnet.org (2020).

2. G. T. Kim, G. H. Kang, and D. 1 Kwon, Effect of Material Property Uncertainty on Warpage during Fan Out Wafer-Level Packaging Process, J. Microelectron. Packag. Soc. 26(1) (2019) 29-33. https://doi.org/10.6117/kmeps.2019.26.1.0029

3. C. I. Chen, C. Y. Ni, C. M. Chang, S. C. Wu, and D. Liu, Bondability Study of Chip-on-Film (COF) Inner Lead Bonding (ILB) Using Conventional Gang Bonder, IEEE Trans. Electro. Packag. Manuf. 31(4) (2008) 285-290.

4. S. J. Kim, W. S. Hong, H. B. Nam, and N. H. Kang, Growth Behavior of Intermetallic Compounds in Various Solder Joints Induced by Electromigration, J. Weld. Join. 39(1) (2021) 89-102. 
https://doi.org/10.5781/JWJ.2021.39.1.11

5. W. S. Hong, W. S. Kim, B. S. Song, and K. B. Kim, Thermal Shock Cycles Optimization of Sn-3.0Ag-0.5 $\mathrm{Cu} /$ OSP Solder Joint with Bonding Strength Variation for Electronic Components, Korean J. Mater. Res. 17(3) (2007) 152-159.

6. W. S. Hong and C. M. Oh, PoF Based Accelerated Life Prediction with 3 Dimensional Packaging Technology Development, J. Korean Weld. Join. Soc. 27(3) (2009) 10-16.

7. W. S. Hong and C. M. Oh, Thermal Shock Reliability of Low Ag Composition Sn-0.3Ag-0.7Cu and Near Eutectic Sn-3.0Ag-0.5Cu Pb-free Solder Joints, J. Kor. Inst. Met. \& Mater. 47(12) (2009) 842-851.

8. D. W. Suh, D. W. Kim, P. Liu, H. C. Kim, J. A. Weninger, C. M. Kumar, A. Prasad, B. W. Grimsley, and H. B. Tejada, Effects of Ag Content on Fracture Resistance of $\mathrm{Sn}-\mathrm{Ag}-\mathrm{Cu}$ Lead-Free Solders under High-Strain Rate Conditions, Mater. Sci. Eng. A. 460(461) (2007) 595-603.

9. JEITA, Lead Free Soldering Technologies, Corona Pub., Tokyo (2003) 26-29.

10. W. S. Kim, W. S. Hong, S. H. Park, and K. B. Kim, Activation Energy and Interface Reaction of $\mathrm{Sn}-40 \mathrm{~Pb} / \mathrm{Cu}$ \& Sn-3.0Ag-0.5Cu/Cu, Korean J. Mater. Res. 17(8) 402 (2007) 402-407.

https://doi.org/10.3740/MRSK.2007.17.8.402
11. J. H. Back, B. S. Lee, S. H. Yoo, D. G. Han, S. B. Jung, and J. W. Yoon, Solderability of Thin ENEPIG Plating Layer for Fine Pitch Package Application, $J$. Microelectron. Packag. Soc. 24(1) (2017) 83-90. https://doi.org/10.6117/kmeps.2017.24.1.083

12. J. Y. Park, M. S. Kim, C. Oh, S. H. Do, J. D. Seo, D. K. Kim, and W. S. Hong, Solder Joint Fatigue Life of Flexible Impact Sensor Module for Automotive Electronics, Korean J. Met. Mater. 55(4) (2017) 232-239. https://doi.org/10.3365/KJMM.2017.55.4.232

13. W. Liu, Y. Tian, C. Wang, and L. Sun, Formation of AuSnx IMCs in Sn3.5Ag0.75Cu Micro-Solder Joints Fabricated by Laser and Hot Air Reflow Processes, J. Mater. Sci. Mater. Electron. 24(1) (2012) 1-7. https://doi.org/10.1007/s10854-012-0715-8

14. J. H. Son, D. Y. Yu, Y. H. Ko, and J. H. Bang, A Study on the Electrochemical Corrosion Property of Sn-xSb Solder Alloy, J. Weld. Join. 36(3) (2018) 78-82. https://doi.org/10.5781/JWJ.2018.36.3.12

15. J. H. Son, M. K. Kim, D. Y. Yu, Y. H. Ko, J. W. Yoon, C. W. Lee, Y. B. Park, and J. H. Bang, Thermal Aging Characteristics of $\mathrm{Sn}-\mathrm{xSb}$ Solder for Automotive Power Module, J. Weld. Join. 35(5) (2017) 38-47. https://doi.org/10.5781/JWJ.2017.35.5.6 


\title{
반도체 검사 프로브 카드용 MEMS 프로브의 레이저 솔더링 접합특성
}

\section{Laser Soldering Properties of MEMS Probe for Semi-conductor Wafer Testing}

\author{
홍원식* · 김미송* · 김명인* · 윤상혁** - 박윤휘** \\ *한국전자기술연구원 융복합전자소재연구센터 \\ **(주)코리아인스트루먼트 기술연구소
}

\section{1. 서 론}

프로브 카드 (Probe card)는 반도체 공정 중 완성 된 웨이퍼 (Wafer) 내 개별 칩 (Chip)의 전기적 동작 여부를 검사하기 위한 검사공정에 사용되는 신호전달 매개체로 사용된다. 프로브 카드는 테스트 (Test) 하는 반도체 소자의 사양에 맞게 개별적으로 설계, 제조하여 주문 제작되는 제품이다. 생산되는 반도체 소자의 사양 이 변경될 때마다 그에 따른 프로브 카드가 새로 제작되 어야 하므로 고부가가치 제품으로 분류된다. 또한 프로 브 카드는 반도체 제조공정 중 전 공정 (Fabrication) 이 완료된 상태에서 Test를 위한 핵심부품 중 하나이 다 ${ }^{1)}$. 형태적으로는 웨이퍼 내 칩의 전기적 동작 상태를 검사하기 위해 아주 미세한 선 형태의 접촉 핀 (Pin) (또 는 프로브)을 일정한 규격의 인쇄회로기판 (Printed Circuit Board, $\mathrm{PCB}$ ) 등에 부착한 카드로, 이 프로 브가 웨이퍼에 접촉되면서 웨이퍼와 측정장비의 중간 매개체 역할을 함으로써 반도체 칩의 양품과 불량을 전 수 검사하게 된다.

최근의 프로브카드 기술은 반도체 공정 노드 미세화 에 따라 메모리 용량 밀도 (Density)가 증가하고, 동 일 용량의 Chip 사이즈 축소 및 웨이퍼당 Net die 수 증가가 지속되고 있다 ${ }^{1,2)}$. 이에 따라, 프로브 카드가 측정해야 하는 $\mathrm{IC}$ 의 pad pitch는 작아지고, pin 수는 급격히 증가하고 있다 ${ }^{1-5)}$. 또한 자동차용 전장품의 경 우, 고온 환경에서 반도체 테스트를 해야 하는 반도체 소자 (IC) 비율이 증가함에 따라, 반도체 제조공정 중 웨이퍼 테스트 온도가 $120^{\circ} \mathrm{C}$ 이상 상승하고 있다. 이 에 따라 프로브와 기판의 솔더 접합부에 대한 고내열 특성 향상도 요구되고 있다.

일반적인 프로브 카드 구조는 다음 Fig. 1과 같이, 전 기적인 신호를 패널 및 반도체 소자 패턴 상에 인가하여 주는 미세 전자기계시스템 (Microelectromechanical

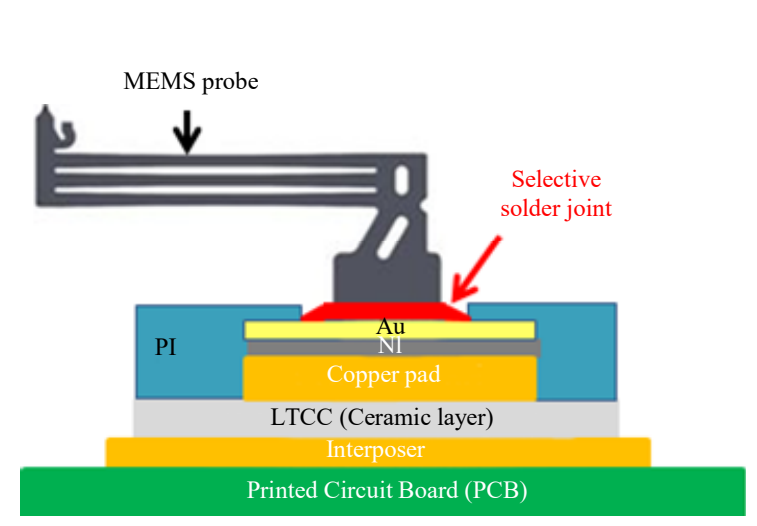

Fig. 1 Schematic diagram of MEMS probe solder joint

systems, MEMS) 프로브, 다층세라믹기판 (Multilayer ceramic, MLC), PCB, 인터포저 (Interposer), 커넥 터 (Connector) 및 기구물로 구성된다. 프로브 카드 는 낮은 접촉저항과 10 만 회 이상의 반복 피로시험 (Fatigue test 또는 Touch down $(\mathrm{T} / \mathrm{D}))$ 에 대한 내 구성 및 사용수명이 보증되어야 하며, $-40^{\circ} \mathrm{C}-100^{\circ} \mathrm{C}$ 조 건에서 열 변형이 작아야 한다 ${ }^{1)}$.

MEMS Probe card는 MLC의 Pad에 무연솔더 ( $\mathrm{Pb}^{-}$ free Solder)를 사용하여 레이저 (Light Amplification by the Stimulated emission of radiation, Laser) 솔더링 공정으로 접합된다. MEMS Probe를 접합하는 방식에는 일반적인 Reflow 방식이 있으나, $\mathrm{MLC}$ 기판 에 열적 스트레스가 인가되어 회로의 단락 및 기판의 파손 가능성이 높기 때문에 MEMS Probe를 MLC 기 판의 개별 $\mathrm{Pad}$ 에 Laser를 사용하여 접합하는 선택적 솔더링 (Selective soldering) 방식이 사용된다. Laser soldering 공정은 수십-수백 $\mu \mathrm{m}$ 크기의 $\mathrm{Pad}$ 에 독립적 으로 Laser otpic을 통해 열원을 공급하여 접합하기 때문에, $\mathrm{MLC}$ 기판에 열적 및 기계적인 스트레스를 인 가시키지 않는 장점이 있다. Probe 솔더 접합을 위해 사용되는 Solder는 $\mathrm{Pb}-\mathrm{Sn}$ 솔더에서 최근 친환경 $\mathrm{Pb}-$ free 솔더가 적용되고 있다. 주로 사용되는 무연솔더는 
$\mathrm{Sn}-3.0 \mathrm{Ag}-0.5 \mathrm{Cu}$ (SAC305)가 사용되고 있으며, 내 열특성 향상을 위해 융점이 높은 $\mathrm{Sn}-0.7 \mathrm{Cu}$ 또는 $\mathrm{Sn}^{-}$ $5 \mathrm{Sb}$ 와 같은 솔더의 적용 이 검토되고 있다.

따라서 본 연구에서는 고온 내열 특성과 미세 피치 대응을 위한 프로브-MLC Laser soldering 접합공정을 개발하였다. 이를 위해 SAC305 Type 4 (T4) (Power size: 20-38 $\mu \mathrm{m}$ )와 Type 7 ( $\mathrm{T} 7$ ) (Power size: 2$11 \mu \mathrm{m})$ 솔더 페이스트 (Paste)를 사용하였다. 또한 Low$\mathrm{Ag}$ 함유된 솔더의 접합특성 비교를 위해 $\mathrm{Sn}-0.3 \mathrm{Ag}-$ $0.7 \mathrm{Cu}$ ( $\mathrm{SAC} 0307) \mathrm{T} 4$ 솔더를 사용하였고, 고온 대 응을 위한 $\mathrm{Sn}-5.0 \mathrm{Sb}$ ( $\mathrm{SnSb}$ ) T4 솔더를 사용하여 프 로브 접합공정을 진행하였다. 이후 접합부의 고온 내열 특성 비교를 위해 열충격시험을 수행하였으며, 시험 전 후 프로브 솔더 접합부의 전단강도를 측정하였고, 초기 솔더 접합부의 단면 미세조직 분석을 통한 솔더 접합특 성을 비교분석 하였다.

\section{2. 실험 방법}

\subsection{Probe, MLC 및 무연솔더 페이스트}

Fig. 2는 실험에 사용된 Probe와 MLC 기판 사진 이다. MEMS Probe는 25-34 $\mu \mathrm{m}$ 두께의 금 $(\mathrm{Au})$ 도 금된 니켈 합금을 사용하였다. MLC 기판은 $25(\mathrm{~L}) \times$ 25 (W) $\mathrm{mm}$ 이였으며, Probe가 접합될 $\mathrm{Pad}$ 크기는 $750(\mathrm{~L}) \times 120(\mathrm{~W}) \mu \mathrm{m}$ 이고, Pad pitch는 $250 \mu \mathrm{m}$
이었다. $\mathrm{Cu} \mathrm{Pad}$ 두께는 약 $23 \mu \mathrm{m}$ 였고, $\mathrm{Cu}$ Pad는 $\mathrm{Ni} / \mathrm{Au}$ 도금으로 표면처리하였다.

Probe 접합에 사용된 솔더는 다음 Table 1에 나타 낸 것과 같이 총 4 종의 솔더 Paste를 사용하였는데, 현재 사용되고 있는 $\mathrm{T} 4 \mathrm{SAC} 305$ 와 미세피치 대응을 위한 T7 SAC305 솔더를 사용하였다. 또한 Low-Ag 솔더가 나타내는 피로특성 향상을 비교하기 위해 $\mathrm{T} 4$ $\mathrm{SAC} 0307$ 솔더를 사용하였다. 고온 내열특성 검토를 위해 $\mathrm{SnSb}$ 솔더를 사용한 솔더링 공정을 진행하였다.

\section{2 레이저 솔더링 접합공정 및 레이저 출력 프로파일}

Probe와 MLC 접합공정에는 Laser를 사용한 솔더 링 공정을 실시하였다. Fig. 3은 수행된 레이저 솔더링 공정을 나타낸 사진이다. 실험에 사용된 화이버 (Fiber) 레이저 소스는 파장 $808 \mathrm{~nm}$, 파장 허용오차 범위 $\pm 3 \mu \mathrm{m}$, 출력 $55 \mathrm{~W}$ 의 nLight사 Pearl Model 장비다.

레이저 솔더링 공정에 사용된 레이저 솔더링 프로파 일은 Fig. 4와 같다. Fig. 4(a)는 SAC305 솔더를 위한 레이저 프로파일이며, Fig. 4(b)는 SnSb용 레이 저 프로파일을 나타낸다. SAC305 솔더링에는 총 $2.5 \mathrm{~s}$, $\mathrm{SnSb}$ 솔더링에는 총 $3 \mathrm{~s}$ 의 접합시간 동안 레이저를 조사하여 접합공정을 진행하였다. 융점 $217{ }^{\circ} \mathrm{C}$ 의 $\mathrm{SAC} 305$ 솔더에 비해 융점 $232-240{ }^{\circ} \mathrm{C} \mathrm{SnSb}$ 솔더 의 경우, $16 \mathrm{~A}$ 에서 $0.5 \mathrm{~S}$ 를 추가하여 레이저를 조사
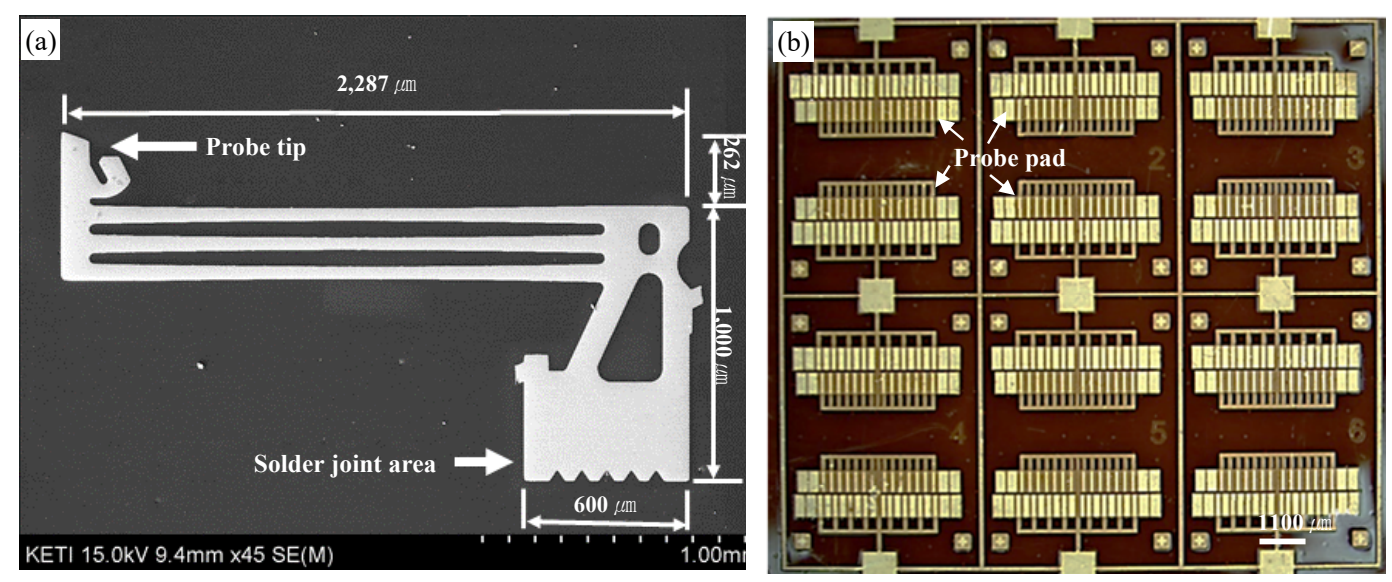

Fig. 2 SEM micrograph of (a) MEMS probe and optical stereo-microscope image of (b) MLC

Table 1 Chemical composition, type, and powder size of $\mathrm{Pb}$-free solder pastes

\begin{tabular}{|c|c|c|c|}
\hline Solder alloy composition & Solder paste type & Powder size $(\mu \mathrm{m})$ & Manufacturer \\
\hline \multirow{2}{*}{ Sn-3.0Ag-0.5Cu (SAC305) } & $\mathrm{T} 4$ & $20-38$ & Ecojoin Co., Ltd.(Korea) \\
\cline { 2 - 4 } & $\mathrm{T} 7$ & $2-11$ & Duksan Hi-Metal Co., Ltd.(Korea) \\
\hline $\mathrm{Sn}-0.3 \mathrm{Ag}-0.7 \mathrm{Cu}(\mathrm{SAC} 0307)$ & $\mathrm{T} 4$ & $20-38$ & Ecojoin Co., Ltd.(Korea) \\
\hline $\mathrm{Sn}-5.0 \mathrm{Sb}(\mathrm{SnSb})$ & & & \\
\hline
\end{tabular}

본 논문은 독자의 이해를 돕기위하여 영문논문을 국문으로 번역하여 게재한 논문입니다. 저자는 본 논문으로 연구업적과 같은 실적에 중복으로 지원받거나 인정받을 수 없음을 알려드립니다. 

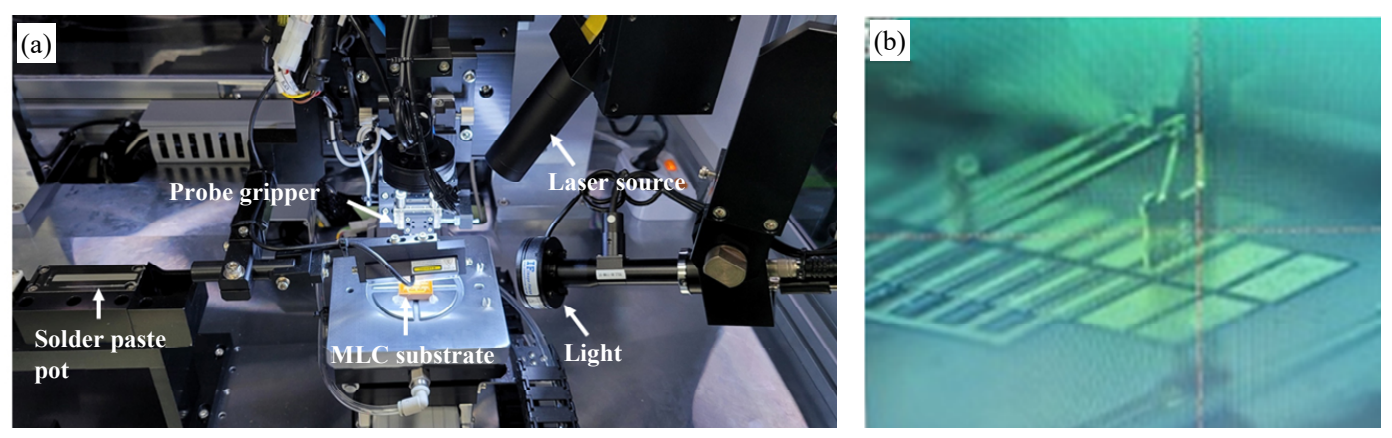

Fig. 3 Photographs of (a) laser soldering process with (b) MEMS probe and MLC

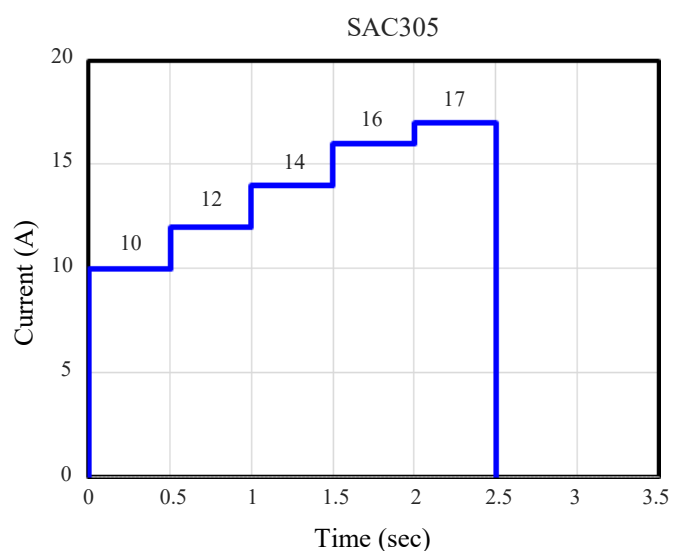

(a)

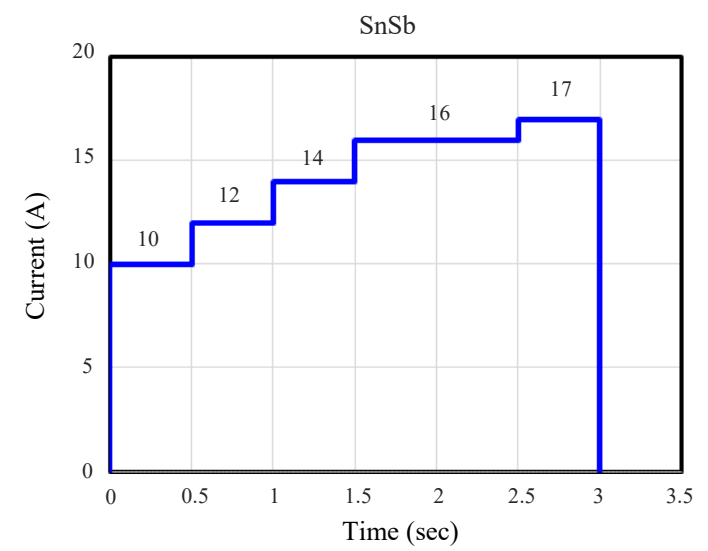

(b)

Fig. 4 Laser soldering profiles for (a) SAC305 and (b) SnSb solders

하였다. 이것은 융점이 높기 때문에, 고출력의 레이저를 추가로 조사하여 솔더의 완전한 용융을 유도하기 위한 것이다.

\section{3 열충격시험}

Probe 접합부에 대한 접합강도 열화특성 분석을 위 해 TCT를 $-25-105{ }^{\circ} \mathrm{C}$, 각 온도 유지시간 $10 \mathrm{~min}$ 조 건에서 500 cycles 진행하였다 ${ }^{5,6)}$. 이후 Probe 접합
부에 대한 전단강도를 측정하였다. 일반적으로 $\mathrm{TCT}$ 후 접합강도 기준은 초기 대비 약 $40 \%$ 이내 이다.

\section{4 솔더 접합부 접합강도 측정}

Probe-MLC 솔더 접합부의 접합강도 측정은 Dage 4000 (Nordson Co., Ltd., USA) 장비를 사용하여 Fig. 5 와 같이 전단강도 측정시험 (Shear strength test)을 진행하였다. 전단강도 시험은 전단속도 $50 \mu \mathrm{m} / \mathrm{sec}$, 시
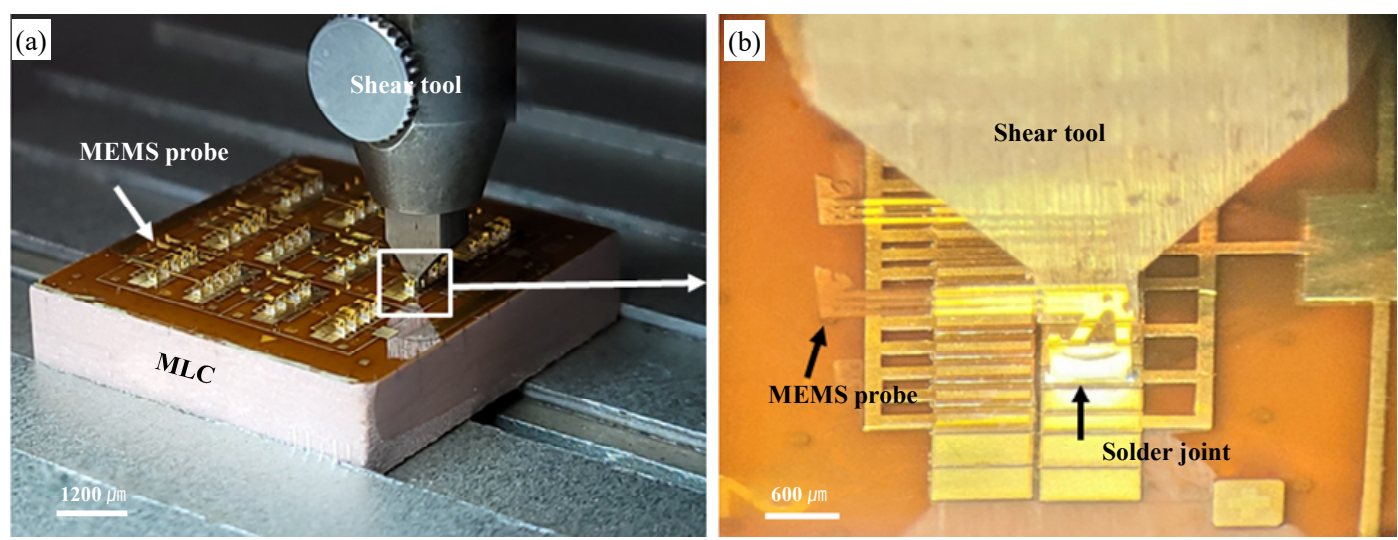

Fig. 5 Photographs of shear strength measurement of probe solder joint, (a) overview of probe-MLC bonded coupon and (b) magnified view of probe solder joint

본 논문은 독자의 이해를 돕기위하여 영문논문을 국문으로 번역하여 게재한 논문입니다. 저자는 본 논문으로 연구업적과 같은 실적에 중복으로 지원받거나 인정받을 수 없음을 알려드립니다. 
험치구 높이는 기판으로부터 $500 \mu \mathrm{m}$ height 조건으로 측정 하였으며, 솔더의 합금 종류와 Type에 따른 접합 강도를 비교분석 하였다.

\section{3. 실험 결과}

\section{1 프로브 솔더 접합부 접합강도}

프로브 접합부에 대한 접합강도 열화특성 분석을 위 해 TCT 500 cycles 시험 후 프로브 솔더 접합부의 전단강도를 측정하여 초기대비 열화정도를 비교분석한 결과를 Fig. 6에 나타내었고, 모든 샘플에서 초기대비 0\%-17\% 이내의 열화특성을 나타내어 양호한 접합상 태를 나타내었다. $\mathrm{T} 4$ 와 $\mathrm{T} 7 \mathrm{SAC} 305$ 솔더 접합부는 $54.9 \mathrm{gf}$ 와 $48.7 \mathrm{gf}$ 였으며, TCT 후는 각각 $45.5 \mathrm{gf}$ 와 $46.6 \mathrm{gf}$ 였다. T4 $\mathrm{SAC} 305$ 가 $\mathrm{T} 7 \mathrm{SAC} 305$ 보다 초기 접합강도는 다소 높게 나타났지만, $\mathrm{TCT}$ 후 열화 비율은 각각 $17.1 \%$ 와 $5.5 \%$ 로, $\mathrm{T} 7$ 솔더가 낮은 열화 율을 보였다. T4 SAC0307은 초기 48.2 gf에서 TCT 후 $42.7 \mathrm{gf}$ 로 감소되어 그 강도가 $11.4 \%$ 감소되었다. $\mathrm{T} 4$ SAC0307 솔더 접합부는 T4 SAC305 보다 초기 접 합강도는 다소 낮지만, TCT 후 열화율이 T4 SAC305

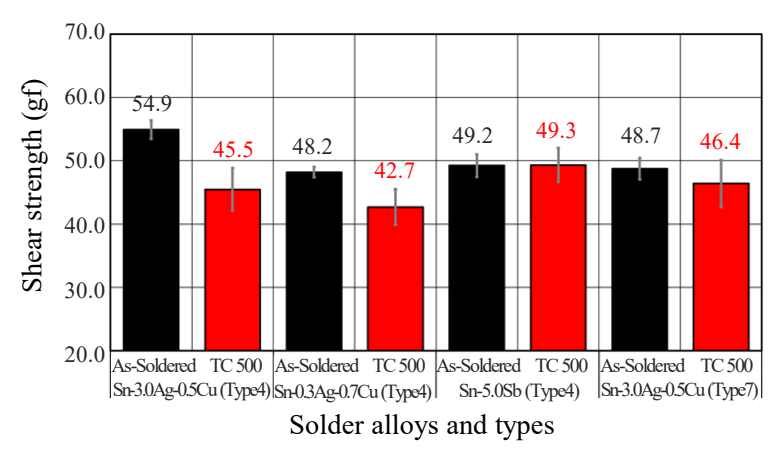

Fig. 6 Shear strength comparison of laser solder joints before and after thermal cycles
보다 작게 나타났으며, T7 SAC305의 초기 접합강도 와 유사한 수준 이였다. $\mathrm{T} 4 \mathrm{SnSb}$ 솔더 접합부의 경 우, $\mathrm{T} 4 \mathrm{SAC} 305$ 보다 초기 접합강도는 낮지만, $\mathrm{T} 4$ $\mathrm{SAC} 0307$ 과 $\mathrm{T} 7 \mathrm{SAC} 305$ 접합부와는 초기 접합강도 는 동등한 수준 이였고, TCT 500 cycles 후 접합강 도 열화가 전혀 나타나지 않은 것으로 보아, 고온 내열 특성과 열화특성이 우수한 것을 알 수 있었다.

\section{2 솔더 접합부 계면분석}

4종 솔더를 사용하여 Prob-MLC 접합공정 최적화 진행 후 각각의 솔더 접합부에 대한 단면 분석을 수행 한 결과는 다음 Fig. 7과 Fig. 8에 나타내었다. Fig. 8은 Probe-Solder와 Solder-MLC 접합계면의 확대 $\mathrm{SEM}$ 사진이다. Fig. 7 (a,b)는 T4 SAC305, (b,c) $\mathrm{T} 4$ SAC0307, (e,f) T4 SnSb 그리고 $(\mathrm{g}, \mathrm{h}) \mathrm{T} 7$ SAC305 솔더를 사용하여 Probe-MLC 접합 후 단면 SEM 사진이다. Fig. 8 (a-h)는 Probe와 MLC의 4 종 솔더 접합부 사진이며, Fig. 8(i,j)는 Fig. 8 (g,h) $\mathrm{T} 7 \mathrm{SAC} 305$ 접합계면의 확대 SEM 및 EDS 성분분석 결과 이다. Probe 솔더 접합부는 양호한 필렛 (Fillet)을 형성하고 있었고, Probe와 솔더 접합계면에는 다양한 금속간화합물 (Intermetallic compound, IMC)가 형 성된 것이 관찰되었다. Type에 무관하게 SAC305와 $\mathrm{SAC} 0307$ 무연솔더 접합부의 경우, 프로브 솔더 접합 계면에는 $\mathrm{Ni}_{3} \mathrm{Sn}_{4}\left(\mathrm{Cu}, \mathrm{Ni}_{6}\right)_{6} \mathrm{Sn}_{5},(\mathrm{Cu}, \mathrm{Ni}, \mathrm{Au})_{6} \mathrm{Sn}_{5}, \mathrm{IMC}$ 가 형성되었으며, 솔더 모재에는 $\mathrm{Ag}_{3} \mathrm{Sn}, \mathrm{Au}_{\mathrm{x}} \mathrm{Sn}_{\mathrm{y}}, \mathrm{Cu}_{6} \mathrm{Sn}_{5}$, $(\mathrm{Cu}, \mathrm{Ni}, \mathrm{Au})_{6} \mathrm{Sn}_{5} \mathrm{IMC}$ 가 형성되었다 ${ }^{7-15)}$. Probe 표면 이 $\mathrm{Ni} / \mathrm{Au}$ 도금되어 있기 때문에, 솔더 접합부 내부에 서는 다양한 종류의 $\mathrm{Au}-\mathrm{Sn} \mathrm{IMC}$ 가 관찰되었다. 형성 가 능한 $\mathrm{Au}-\mathrm{Sn} \mathrm{IMC}$ 로는 $\mathrm{AuSn}, \mathrm{Au}_{2} \mathrm{Sn}, \mathrm{AuSn}_{2}, \mathrm{AuSn}_{4}$ 의 4종이다 ${ }^{8}$. Fig. $7(\mathrm{~b}, \mathrm{~d}, \mathrm{~h})$ 에서 $\mathrm{SAC} 305$ 솔더 내 부에 형성된 미세조직을 비교해 보면, SAC0307이
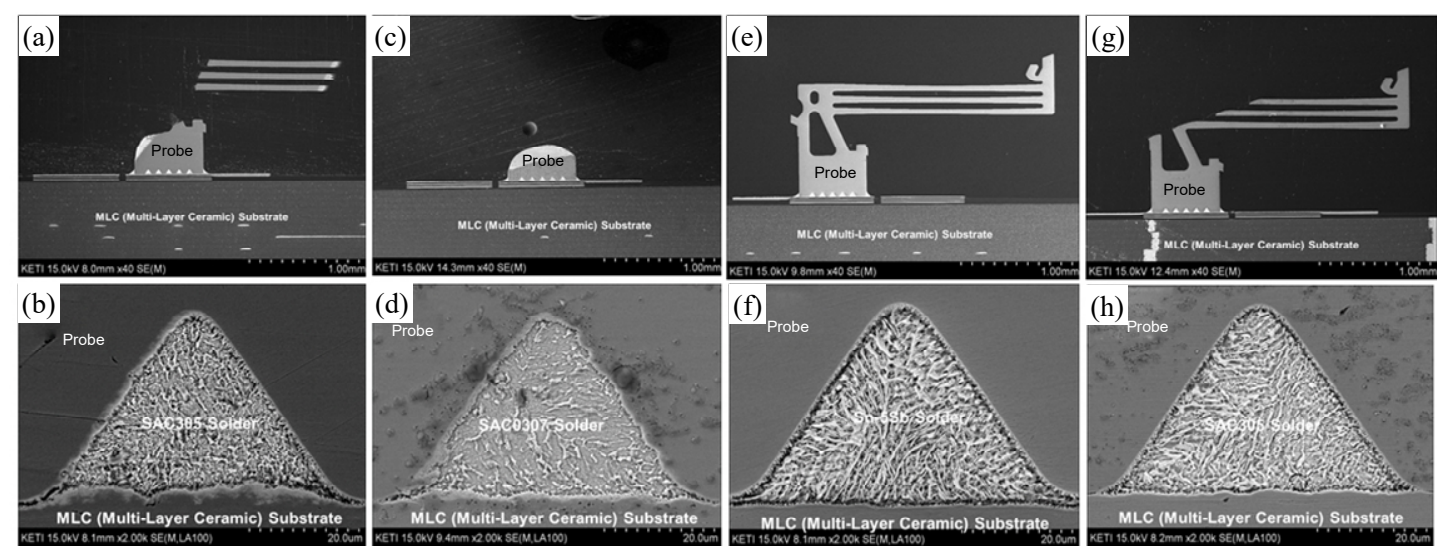

Fig. 7 Cross-sectional SEM micrographs of as-soldered probe-MLC joints, (a,b) T4 SAC305, (b,c) T4 SAC0307, (e,f) T4 $\mathrm{SnSb}$, and $(\mathrm{g}, \mathrm{h}) \mathrm{T} 7 \mathrm{SAC} 305$

본 논문은 독자의 이해를 돕기위하여 영문논문을 국문으로 번역하여 게재한 논문입니다. 저자는 본 논문으로 연구업적과 같은 실적에 중복으로 지원받거나 인정받을 수 없음을 알려드립니다. 

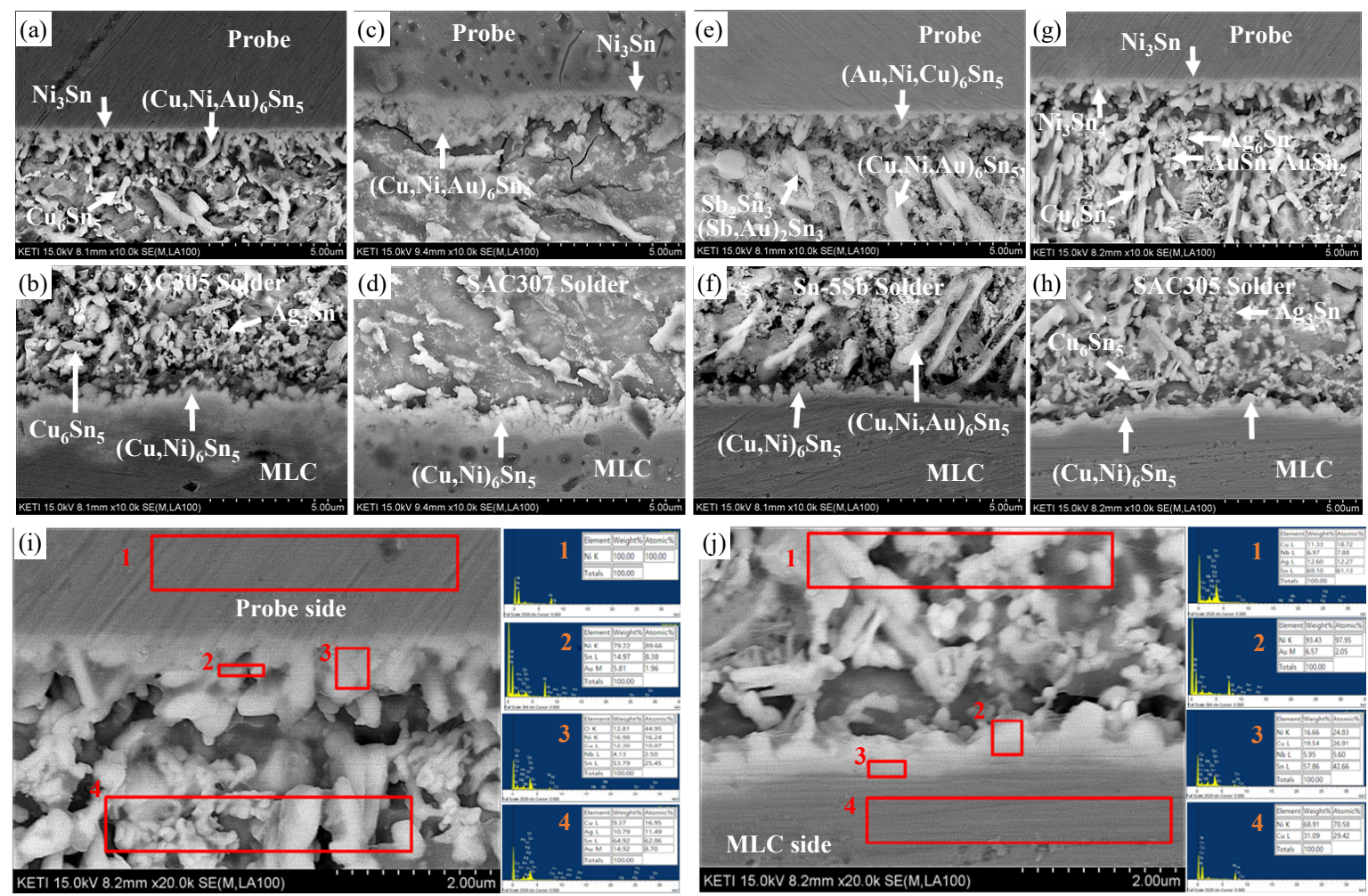

Fig. 8 Magnified SEM images of as-soldered Probe-MLC joints, (a,b) T4 SAC305, (b,c) T4 SAC0307, (e,f) T4 SnSb, $(\mathrm{g}, \mathrm{h}) \mathrm{T} 7 \mathrm{SAC} 305$, and $(\mathrm{i}, \mathrm{j})$ magnified images of the probe and the MLC joint of T7 SAC305

$\mathrm{SAC} 305$ 보다 $\mathrm{Ag}_{3} \mathrm{Sn} \mathrm{IMC}$ 가 적게 형성된 것을 알 수 있다. 이것은 솔더에 포함되어 있는 $\mathrm{Ag}$ 의 함량에 차이 에 의해 솔더 모재에 형성되는 $\mathrm{Ag}_{3} \mathrm{Sn}$ 양이 달라지기 때문이다. $\mathrm{Hong}^{7}$ 과 $\mathrm{Suh}^{8)}$ 의 연구결과에 따르면, $\mathrm{Sn}^{-}$ $\mathrm{Ag}-\mathrm{Cu}$ 합금에서 $\mathrm{Sn}$ 의 함량에 따라 primary-Sn의 분율은 $\mathrm{Sn}-3.0 \mathrm{Ag}-0.5 \mathrm{Cu}$ 에서 최대 $11 \%$ 그리고 $\mathrm{Sn}^{-}$ $1.0 \mathrm{Ag}-0.5 \mathrm{Cu}$ 에서는 최대 $35 \%$ 정도가 생성된다고 보 고하였다. $\mathrm{Sn}-\mathrm{Ag}-\mathrm{Cu}$ 합금조성 중 $\mathrm{Ag}$ 함유율이 감소될 수록 primary-Sn의 생성 양이 증가되어 $\mathrm{Ag}_{3} \mathrm{Sn}$ 을 형성 하기 위한 $\mathrm{Sn}$ 의 양은 감소하게 됨으로써 $\mathrm{SAC0307} \mathrm{솔}$ 더에서 $\mathrm{Ag}_{3} \mathrm{Sn}$ 상 분율이 $\mathrm{SAC} 305$ 보다 감소하게 된다 7). 솔더 접합부의 초기 접합강도 향상에 $\mathrm{Ag}_{3} \mathrm{Sn} \mathrm{IMC}$ 는 기여하지만, 고온에 장시간 사용하게 되면, $\mathrm{Ag}_{3} \mathrm{Sn}$ $\mathrm{IMC}$ 는 성장하여 조대화 되기 때문에 접합강도 감소의 원인이 된다 ${ }^{7,10)}$. 이러한 이유 때문에, TCT 후 접합강 도를 비교하면, SAC305가 SAC0307보다 더 많이 접 합강도가 감소된 것을 알 수 있으며, 이것은 모재에 형 성된 $\mathrm{Ag}_{3} \mathrm{Sn} \mathrm{IMC}$ 의 조대화에 따라 감소된 것으로 사 료된다. $\mathrm{SnSb}$ 솔더 접합계면에는 $(\mathrm{Au}, \mathrm{Ni}, \mathrm{Cu})_{6} \mathrm{Sn}_{5}$, $(\mathrm{Cu}, \mathrm{Ni})_{3} \mathrm{Sn}, \mathrm{Ni}_{3} \mathrm{Sn}_{4}, \mathrm{Sb}_{2} \mathrm{Sn}_{3},(\mathrm{Sb}, \mathrm{Au})_{2} \mathrm{Sn}_{3}, \mathrm{AuSn}_{4}$ 등 다양한 $\mathrm{IMC}$ 가 관찰되었다 ${ }^{13-15)}$. 이러한 초기 형성 된 접합부 내의 $\mathrm{IMC}$ 는 솔더링 후 초기 접합강도 향상 에 도움이 되는 것을 알 수 있었으며, $\mathrm{SAC}$ 조성에서
는 $\mathrm{Sn}-\mathrm{Sb} \mathrm{IMC}$ 가 고온 내열특성 향상에 기여하는 것 으로 사료된다.

Fig. 9은 4종 솔더 페이스트 종류에 따른 프로브 솔 더 접합부의 초기 전단강도 측정 후 파단면의 파면을 $\mathrm{SEM}$ 으로 관찰한 사진이다. 모든 샘플의 솔더 접합부 파단면은 Dimple이 다수 존재하는 전형적인 연성파괴 (Ductile fracture)와 취성파괴인 벽개파괴 (Cleavage fracture) 양상이 혼재된 파면을 나타내었다 ${ }^{12)} \mathrm{T} 4$ SAC305 솔더 접합부 파면은 전단시험 초기 Dimple 을 형성하며 연성파괴를 보였지만, 중간 이후부터는 파 면에 요철이 없는 Cleavage fracture의 취성파괴 양 상을 나타내었다. T4 SAC0307의 경우에는 모든 파면 에서 Dimple을 형성하며 연성파괴를 나타낸 것으로 보아 $\mathrm{SAC} 305$ 보다 $\mathrm{Ag}_{3} \mathrm{Sn} \mathrm{IMC}$ 가 적게 형성됨으로써 초기 강도는 감소되지만 연성은 증가된 것을 확인할 수 있었다. $\mathrm{T} 4 \mathrm{SnSb}$ 는 파면에 Dimple이 거의 없는 Cleavage 취성파괴가 주요 파괴모드로 나타났고, 일부 Semi-cleavage fracture surface를 나타내고 있었 다. $\mathrm{SnSb}$ 솔더는 $\mathrm{Sn}-\mathrm{Sb} \mathrm{IMC}$ 형성으로 고온강도가 향상된 솔더로서, 접합강도는 증가되었지만, 연성이 낮 아 취성파괴 (Brittle fracture) 양상을 나타내는 것으 로 관찰되었다. 접합강도 측면에서 $\mathrm{SnSb}$ 솔더는 초기 접합강도가 우수하며, $\mathrm{TCT}$ 후 열화율도 작지만, 솔더 

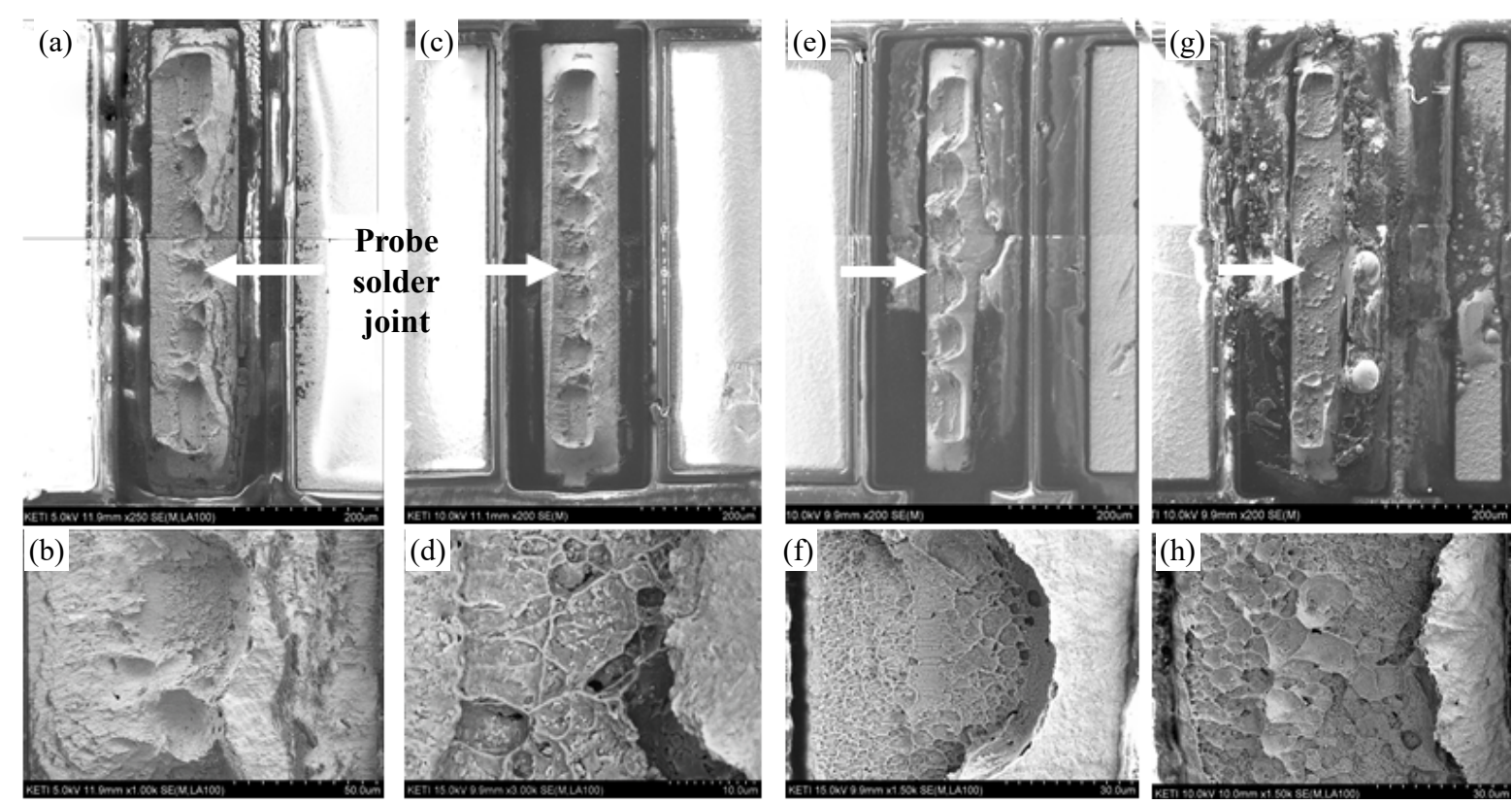

Fig. 9 SEM images of fracture surfaces of as-soldered probe joints after shear strength test, (a,b) T4 SAC305, (b,c) T4 SAC0307, (e,f) T4 SnSb, and (g,h) T7 SAC305

자체의 인성이 $\mathrm{SAC}$ 조성보다 부족하여 파괴시 취성파 괴를 유발하게 되는 것을 알 수 있었다 ${ }^{14,15)}$.

\section{4. 결 론}

본 연구에서는 Probe 솔더 접합부의 고온내열 특성 향상과 미세피치 솔더링 공정 대응을 위해, $\mathrm{T} 4$ 와 $\mathrm{T} 7$ $\mathrm{SAC} 305, \mathrm{~T} 4 \mathrm{SAC} 0307, \mathrm{~T} 4 \mathrm{SnSb}$ 솔더를 사용하여 Probe-MLC Laser soldering 접합공정을 최적하였 으며, $\mathrm{TCT}$ 전후 접합강도 열화비율 및 솔더 합금조성 과 분말입도에 따른 접합특성을 비교분석 하였으며, 그 결과는 다음과 같다.

1) $\mathrm{T} 4 \mathrm{SAC} 305$ 가 $\mathrm{T} 7 \mathrm{SAC} 305$ 보다 초기 접합강 도는 다소 높지만, $\mathrm{TCT}$ 후 $\mathrm{T} 7$ 솔더가 낮은 열화율을 보였다. SAC305 솔더의 경우, T7의 초기 접합강도는 $\mathrm{T} 4$ 보다 작지만, $\mathrm{TCT}$ 후 열화율은 $\mathrm{T} 4$ 보다 작았으 며, T7 SAC0307의 초기 접합강도와 유사하였다. T4 $\mathrm{SnSb}$ 솔더의 경우, $\mathrm{T} 4 \mathrm{SAC} 305$ 보다 초기 접합강도 는 낮지만, $\mathrm{T} 4 \mathrm{SAC} 0307$ 과 $\mathrm{T} 7 \mathrm{SAC} 305$ 와 초기 접 합강도는 동등한 수준 이였고, TCT 500 cycles 후 접합강도 열화는 전혀 나타나지 않은 것으로 보아 고온 내열특성과 열화특성이 우수한 것을 알 수 있었다.

2) SAC305와 SAC0307 솔더 접합부의 경우, Probe 와 $\mathrm{MLC}$ 솔더 접합계면에는 $(\mathrm{Cu}, \mathrm{Ni}, \mathrm{Au})_{6} \mathrm{Sn}_{5} \mathrm{IMC}$ 가 형성되었고, 솔더 내부에는 $\mathrm{Ag}_{3} \mathrm{Sn}, \mathrm{Au}_{3} \mathrm{Sn}, \mathrm{Cu}_{6} \mathrm{Sn}_{5}$, $(\mathrm{Cu}, \mathrm{Ni}, \mathrm{Au})_{6} \mathrm{Sn}_{5} \mathrm{IMC}$ 가 형성되었다. TCT 후 접합강 도 비교결과 $\mathrm{SAC} 305$ 가 $\mathrm{SAC} 0307$ 보다 더 많은 접합
강도 열화를 나타냈다. 이것은 모재에 형성된 $\mathrm{Ag}_{3} \mathrm{Sn}$ 양이 SAC305가 SAC0307 보다 더 많기 때문에, $\mathrm{TCT}$ 후 $\mathrm{Ag}_{3} \mathrm{Sn}$ 조대화로 인해 접합강도가 더 많이 감 소되었다. $\mathrm{SnSb}$ 솔더 접합계면에는 $(\mathrm{Au}, \mathrm{Ni}, \mathrm{Cu})_{6} \mathrm{Sn}_{5}$, $(\mathrm{Cu}, \mathrm{Ni})_{3} \mathrm{Sn}, \mathrm{Ni}_{3} \mathrm{Sn}_{4}, \mathrm{Sb}_{2} \mathrm{Sn}_{3}, \quad(\mathrm{Sb}, \mathrm{Au})_{2} \mathrm{Sn}_{3}, \mathrm{AuSn}_{4}$ 등 다양한 $\mathrm{IMC}$ 가 관찰되었고, $\mathrm{Sn}-\mathrm{Sb} \mathrm{IMC}$ 가 고온 내 열특성 향상에 기여한 것으로 사료된다.

3) SAC 솔더 접합부 파단면은 Ductile fracture와 취성파괴가 혼재된 파면을 나타내었다. T4 SAC0307 파면은 SAC305 보다 더 많은 연성파괴 양상을 나타 냈고, 이것은 솔더 내부에 $\mathrm{Ag}_{3} \mathrm{Sn} \mathrm{IMC}$ 가 적게 형성됨 으로써 연성이 증가된 것으로 판단되었다. $\mathrm{T} 4 \mathrm{SnSb}$ 접합부는 취성파괴인 Cleavage fracture가 주요 파괴 모드로 나타났고, $\mathrm{Sn}-\mathrm{Sb} \mathrm{IMC}$ 로 인해 고온강도가 향 상 되었지만, 연성이 낮아 Brittle fracture를 나타내 었다. 접합강도와 열화율 측면에서 $\mathrm{SnSb}$ 솔더가 우수 한 것으로 보이나, 솔더 자체인성이 부족하여 취성파괴 를 유발하는 것을 알 수 있었다

\section{후기}

본 연구는 산업통상자원부에서 지원한 글로벌주력산 업품질대응 뿌리기술개발사업 (과제번호: 20011705) 의 지원으로 수행된 연구결과입니다.

ORCID: Won Sik Hong: http://orcid.org/0000-0001-8398-177X ORCID: Mi-Song Kim: https://orcid.org/0000-0002-4717-9365 ORCID: Myeongin Kim: https://orcid.org/0000-0002-5151-1404 


\section{References}

1. Korea Institute of Science and Technology Information (KISTI), Technical Tren of Semi-conductor Measurement and Inspection Equipment, The Ministry of Trade, Industry and Energy (MOTIE) and Materials \& Component Technology Network (MCT-Net), Accessed on https://www.mctnet.org (2020).

2. G. T. Kim, G. H. Kang, and D. 1 Kwon, Effect of Material Property Uncertainty on Warpage during Fan Out Wafer-Level Packaging Process, J. Microelectron. Packag. Soc. 26(1) (2019) 29-33.

https://doi.org/10.6117/kmeps.2019.26.1.0029

3. C. I. Chen, C. Y. Ni, C. M. Chang, S. C. Wu, and D. Liu, Bondability Study of Chip-on-Film (COF) Inner Lead Bonding (ILB) Using Conventional Gang Bonder, IEEE Trans. Electro. Packag. Manuf. 31(4) (2008) 285-290.

4. S. J. Kim, W. S. Hong, H. B. Nam, and N. H. Kang, Growth Behavior of Intermetallic Compounds in Various Solder Joints Induced by Electromigration, J. Weld. Join. 39(1) (2021) 89-102. https://doi.org/10.5781/JWJ.2021.39.1.11

5. W. S. Hong, W. S. Kim, B. S. Song, and K. B. Kim, Thermal Shock Cycles Optimization of Sn-3.0Ag-0.5 $\mathrm{Cu} /$ OSP Solder Joint with Bonding Strength Variation for Electronic Components, Korean J. Mater. Res. 17(3) (2007) 152-159.

6. W. S. Hong and C. M. Oh, PoF Based Accelerated Life Prediction with 3 Dimensional Packaging Technology Development, J. Korean Weld. Join. Soc. 27(3) (2009) 10-16.

7. W. S. Hong and C. M. Oh, Thermal Shock Reliability of Low Ag Composition Sn-0.3Ag-0.7Cu and Near Eutectic Sn-3.0Ag-0.5Cu Pb-free Solder Joints, J. Kor. Inst. Met. \& Mater. 47(12) (2009) 842-851.
8. D. W. Suh, D. W. Kim, P. Liu, H. C. Kim, J. A. Weninger, C. M. Kumar, A. Prasad, B. W. Grimsley, and H. B. Tejada, Effects of Ag Content on Fracture Resistance of $\mathrm{Sn}-\mathrm{Ag}-\mathrm{Cu}$ Lead-Free Solders under High-Strain Rate Conditions, Mater. Sci. Eng. A. 460(461) (2007) 595-603.

9. JEITA, Lead Free Soldering Technologies, Corona Pub., Tokyo (2003) 26-29.

10. W. S. Kim, W. S. Hong, S. H. Park, and K. B. Kim, Activation Energy and Interface Reaction of $\mathrm{Sn}-40 \mathrm{~Pb} / \mathrm{Cu}$ \& Sn-3.0Ag-0.5Cu/Cu, Korean J. Mater. Res. 17(8) 402 (2007) 402-407. https://doi.org/10.3740/MRSK.2007.17.8.402

11. J. H. Back, B. S. Lee, S. H. Yoo, D. G. Han, S. B. Jung, and J. W. Yoon, Solderability of Thin ENEPIG Plating Layer for Fine Pitch Package Application, $J$. Microelectron. Packag. Soc. 24(1) (2017) 83-90. https://doi.org/10.6117/kmeps.2017.24.1.083

12. J. Y. Park, M. S. Kim, C. Oh, S. H. Do, J. D. Seo, D. K. Kim, and W. S. Hong, Solder Joint Fatigue Life of Flexible Impact Sensor Module for Automotive Electronics, Korean J. Met. Mater. 55(4) (2017) 232-239. https://doi.org/10.3365/KJMM.2017.55.4.232

13. W. Liu, Y. Tian, C. Wang, and L. Sun, Formation of AuSnx IMCs in Sn3.5Ag0.75Cu Micro-Solder Joints Fabricated by Laser and Hot Air Reflow Processes, J. Mater. Sci. Mater. Electron. 24(1) (2012) 1-7. https://doi.org/10.1007/s10854-012-0715-8

14. J. H. Son, D. Y. Yu, Y. H. Ko, and J. H. Bang, A Study on the Electrochemical Corrosion Property of $\mathrm{Sn}-\mathrm{xSb}$ Solder Alloy, J. Weld. Join. 36(3) (2018) 78-82. https://doi.org/10.5781/JWJ.2018.36.3.12

15. J. H. Son, M. K. Kim, D. Y. Yu, Y. H. Ko, J. W. Yoon, C. W. Lee, Y. B. Park, and J. H. Bang, Thermal Aging Characteristics of $\mathrm{Sn}-\mathrm{xSb}$ Solder for Automotive Power Module, J. Weld. Join. 35(5) (2017) 38-47. https://doi.org/10.5781/JWJ.2017.35.5.6 